\title{
共鳴効果を利用する生体分子の 部位特異的ダイナミクス観測
}

\author{
水野操·水谷泰久 \\ 大阪大学大学院理学研究科化学専攻 豊中市待兼山町 1-1（甬560-0043） \\ (2008年 5 月 26 日受領， 2008年 6 月 19 日受理)
}

Site-specific Observation of Dynamics in Biological Molecules Utilizing Resonance Effect

Misao Mizuno and Yasuhisa MizuTANI

Department of Chemistry, Graduate School of Science, Osaka University
1-1 Machikaneyama, Toyonaka, 560-0043, Japan

(Received May 26, 2008; Accepted June 19, 2008)

\begin{abstract}
Protein dynamics are intimately connected to the structure/function relationship of biological systems. The dynamics spans over a wide range of time scales from the earliest moments, such as the picosecond regime, toward time scales highly relevant to biological functions, such as the microsecond or millisecond regimes. We have been studying protein dynamics by using time-resolved resonance Raman spectroscopy, which is sufficiently structure sensitive at a chemical-bond resolution. One of the advantages of resonance Raman spectroscopy over other spectroscopy is selectivity due to resonance effect. By taking advantage of resonance effect, we can investigate specific parts of protein by using different excitation wavelengths. Thus, this technique is suitable for examining how proteins change their shape in response to external stimuli. In this review, we summarize recent progresses in resonance Raman studies on protein dynamics.
\end{abstract}

Keywords: resonance Raman spectroscopy, time-resolved spectroscopy, protein dynamics

\section{1.はじめに}

Francis Crick が, "If you want to understand function, study structure”という言葉で表現したように，タンパク 質が機能するしくみを理解するうえで, その分子構造を知 ることはきわめて重要である.1960年代以降，X線回折 法をはじめとする立体構造解析が多くのタンパク質につい てなされ，構造に基づいた理解は大きく進展した。しかし その過程で, 機能を理解するには安定な構造（静的立体構 造）だけでなく，タンパク質構造の動的性質を知る重要性 も強く認識されるようになってきた. タンパク質は安定性 と柔軟性を併せ持つことに特徵があり, 必要に応じてその 構造を変化させる．その代表例が，へモグロビン（Hb） の協同性など，構造変化によって活性制御がなされる，ア ロステリーとよばれる性質である11)。また，タンパク質が 機能するためには，摇らぎも重要である，例えば，基質の 取り込みにおいては，摇らぎによる経路形成が必須である
ことがいくつかのタンパク質について知られている ${ }^{2-4)}$. 以上のように, 構造変化と機能発現機構は直結した問題で あり，両者の関係を明らかにすることがタンパク質科学の 新しい課題として注目されている.

上記の構造変化によるタンパク質の機能発現を, 分子の 問題として考えてみよう. タンパク質機能は, 分子ダイナ ミクスの観点からは，「リガンドの結合や光の吸収など, 外部からの摂動に対して, 構造変化という形の分子応答に よる化学反応の制御」ととらえることができる. タンパク 質という分子には, 外部摂動を受ける部分, すなわち, 機 能発現のスイッチ部と, 機能に直接かかわる部分, すなわ ち, 機能発現の作動部がある.これらふたつは分子内で互 いに隣接しているのではなく, 離れて存在する. タンパク 質という分子機械では, スイッチ部と作動部の間を, 構造 変化を介して情報を伝えているのである（図 1).

タンパク質の分子としての特徵は, サブピコ秒から秒ま での幅広い時間スケール，サブオングストロームから数十 


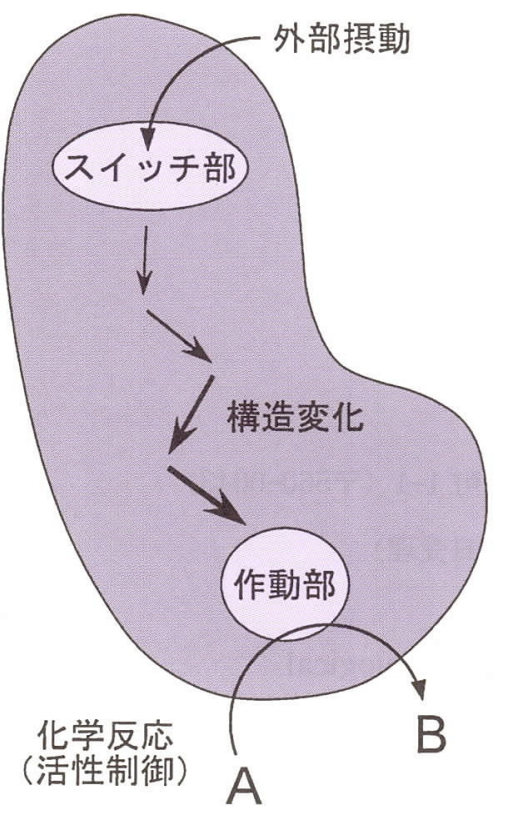

図 1 連動性が生み出すタンパク質機能.

オングストロームまでの幅広い空間スケールに，さまざま なダイナミクスが存在し，互いに連動しているところにあ る。そして, この連動性が，外部摂動による局所的な構造 变化から機能を制御する大域的な構造変化を生み出す。つ まり，連動性こそがタンパク質分子の動的性質の特徴であ り，機能することの鍵である，連動性は分子として自明の 性質ではない.なぜ複数の素過程がうまく連動しているの かを明らかにすることは，分子素過程の理解が進んだ現 在, 次のステップの分子科学として取り組むべき課題であ る. それは，小さな分子からの応用問題では決してなく， 分子一般に対しても深い理解をもたらすであらう。ここ に, この学術分野を「タンパク質の分子科学」とよぶ理由 がある。

本稿では，「連動性が生み出すタンパク質機能の分子科 学」という視点から, 時間分解共鳴ラマン分光法を用いた タンパク質ダイナミクス研究を, 筆者らの研究を中心に紹 介する。

\section{2. 共鳴ラマン分光法}

機能を生み出す構造变化を明らかにするには，化学結合 スケールあるいはそれ以下のスケールで，変化をとらえる 必要がある. 現在, タンパク質の立体構造研究の主要な手 法は, タンパク質結晶に対するX線回折法である。これ は, X線の回折パターンから電子の密度分布, すなわち 原子の存在位置データを求める方法である。これに対して 振動分光法は，原子位置に関する直接的な情報を与えるわ けではない。しかし，振動スペクトルは原子位置の変化に 対して大変敏感に変化するので，振動バンドの振動数や強 度などが分子構造とうまく相関づけられる場合には，構造 変化を感度よく検出することができる，例えば，ある化学
結合に局在した伸縮振動モードでは, 振動数の変化は結合 距離の変化に対応づけられる. 通常のスペクトル測定では, $1 \%$ 振動数差を検出することは容易であるので，ここか ら結合距離としてピコメートルの変化を検出することがで きる、また，後述のように，へム，レチナール，アミノ酸 など生体分子として重要なものの多くは，これまでの研究 データの蓄積から，スペクトルー分子構造の相関がよくわ かって抢り，マーカーバンドの解釈が確立している。これ に基づき, 構造変化に関する詳しい情報を得ることができ る。これらの特徵は，時間分解スペクトルからタンパク質 の構造ダイナミクスを調べるうえで大変有効である．X 線回折法が,「タンパク質の構造がどのようであるか」を 知るのに適しているのに対し, 振動分光法は, 「ある過程 に㧍いてタンパク質の構造がどのように变化するか」を知 るのに適しているといえるだろう。

振動スペクトルは, 構造変化を感度よく検出するのに有 効である。しかし，タンパク質という大きな分子全体をそ の末ま対象にしては, スペクトルが複雑すぎて, 個々の分 子振動を分離して観測することはきわめて困難である。共 鳴ラマン分光法は, 分子の電子遷移に合う波長でラマン散 乱を励起すると，散乱強度が著しく（104-106 倍）増大す るという現象を利用したラマン分光法の一種である。この 特色を用いると，タンパク質という巨大な分子の中で，特 定の部位の振動スペクトルを選択的に観測することが可能 になる，さらに，励起波長を変えることによって，タンパ ク質のさまざまな部位を特異的に観測することが可能であ る. 例えば, 可視領域の励起波長を用いると, ヘムタンパ ク質中のヘム，レチナールタンパク質中のレチナールなど 可視域に吸収帯をもつ補欠分子族の振動スペクトルを選択 的に観測することができる。一方，紫外域では，タンパク 質部分に含まれる芳香族アミノ酸残基側鎖やペプチド結合 に由来する振動モードが共鳴効果を受ける：このように， 波長老適切に選ぶことによって，巨大な分子のさまざまな 部位を選択的に観測することができる。さらに，これを時 間分解測定することによって，「どの部位に，どの時間帯 で，どのような構造変化が起きるのか」という情報を実験 的に得ることができる，そして，得られた動的構造情報を 相互につき合わせることによって，それぞれの部位のダイ ナミクスの間にどのような関係があるかを明らかにでき る. 以上の上うに, 時間分解共鳴ラマン分光法は, 高い時 間分解能で, タンパク質の部位特異的な情報が得られると いう点で, タンパク質の連動性による機能発現の研究にき わめて有効である. 以下， タンパク質の共鳴ラマンスペク トルについて，詳細を説明する.

\section{1 ヘム}

ヘムタンパク質は, 共鳴ラマン分光法の黎明期から研究 が行われているタンパク質である. 異常偏光解消度が実験 的に初めて観測されたのも, チトクロムcとよばれるへム 
タンパク質である ${ }^{5)}$ 、へムタンパク質は, 補欠分子族とし てへム（鉄ポルフィリン錯体の一種. 代表的なへムである プロトポルフィリン IX 鉄錯体の分子構造を図 2 に示す.) をもつタンパク質の総称であり, 生体内では, 酸素 $\left(\mathrm{O}_{2}\right)$ 運搬抢よび貯蔵, 電子伝達, 酸化還元反応の触媒など, 重 要な化学反応に関わっている.

へムは, 400-450 $\mathrm{nm}$ にモル吸光係数, 約 $10^{5} \mathrm{~cm}^{-1}$. $\mathrm{mol}^{-1}$ の，500-600 nm にモル吸光係数, 約 $10^{4} \mathrm{~cm}^{-1}$. $\mathrm{mol}^{-1}$ の電子吸收帯をもつ。これら可視領域の光を用い て，ヘムタンパク質の共鳴ラマンスペクトルを測定する と, ポルフィリン骨格に由来するラマンバンドが選択的に 観測される. 金属ポルフィリンの面内振動モードの㷌属お よび基準振動解析は, Kitagawa, Abeらによってなさ れ6,7), 現在はそのナンバリングが用いられている. 後に,

Spiroのグループによって，側鎖の振動モードまで含めた 面内振動モードの解析 ${ }^{8)}$ (Kitagawa, Abe らの解析では, 側鎖をひとつの運動単位として近似していた）およで面外 振動の解析がなされた ${ }^{9)}$ 。 また，同位体標識したプロトポ ルフィリン IX 鉄錯体をミオグロビン $(\mathrm{Mb})$ 中に再構成 することで, タンパク質中のへムについても振動モードの 解析と帰属が行われている10).

帰属された振動モードの多くは, ヘムのマーカーバンド

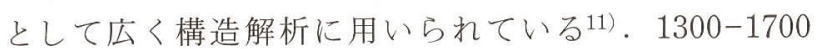
$\mathrm{cm}^{-1}$ に観測される， C-N 伸縮振動および C-C 伸縮振動 に由来するいくつかのラマンバンドは, へム鉄の酸化還元 状態抢よびスピン状態（へム鉄の配位数と相関）を敏感に 反映することがよく知られている．通常へムの共鳴ラマン スペクトルには, $1350 \mathrm{~cm}^{-1}$ 付近に最も強いラマンバンド が観測される。これは $v_{4}$ モードとよばれる， $\mathrm{C}_{\alpha}-\mathrm{N}$ 伸縮振 動を主に含むモードであり，その振動数はへム鉄の価数に 敏感である.この相関は, へム鉄の $\mathrm{d}_{\pi}$ 軌道からポルフィ リン環の $\pi^{*}$ 軌道への逆供与によって説明されてい

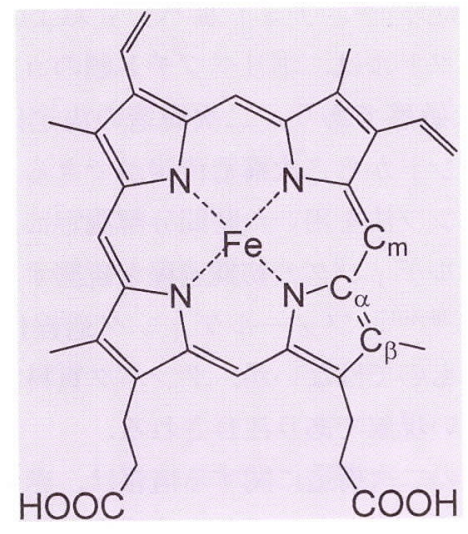

図 2 プロトポルフィリンIX 鉄錯体の分子構造. ピロール 環どうしをつなぐ炭素を $\mathrm{C}_{\mathrm{m}}$, ピロール環に含まれる 炭素のうち, $\mathrm{C}_{\mathrm{m}}$ と結合している炭素を $\mathrm{C}_{\alpha}$, 結合して いない炭素を $\mathrm{C}_{\beta}$ とよぶ.
る12,13). また, $1630 \mathrm{~cm}^{-1}$ 付近, $1600 \mathrm{~cm}^{-1}$ 付近, 1590 $\mathrm{cm}^{-1}$ 付近には， $v_{10}$ モード， $v_{2}$ モード， $v_{3}$ モードとよば れるモードが観測される。これらは， $\mathrm{C}_{\beta}-\mathrm{C}_{\beta}$ 伸縮振動， $\mathrm{C}_{\alpha}$ $-\mathrm{C}_{\mathrm{m}}$ 伸縮振動の性格を多く含んでいる。これらは, へム鉄 のスピン状態に敏感であり，したがってへム鉄の配位数に 敏感である.この相関は, スピン状態の変化によるポルフ ィリン環の変形によると理解されている ${ }^{14,15)}$. すなわち, スピン状態によってへム鉄とピロールの窒素原子との相互 作用が異なるために, 高スピン状態では, ポルフィリン環 のコアサイズが広がり変形する.この変形では, 主に $\mathrm{C}_{\alpha}-$ $\mathrm{C}_{\mathrm{m}}$ 結合が伸びるため, $\mathrm{C}_{\alpha}-\mathrm{C}_{\mathrm{m}}$ 伸縮振動を性格に含んだ振 動モードの振動数が変化する.

上記のバンドはあらゆるへムに共通して観られるもので あるが，タンパク質によってはこれ以外に，鉄-軸配位子 伸縮振動が観測される。このラマンバンドを調べることで 軸配位子の同定ができるほか，へム鉄と軸配位子との相互 作用変化をとらえることもできる. そのため, 軸配位子の ラマンバンドの検出が反応機構の解明に決定的な役割を果 たしてきた．特に，鉄ーヒスチジン伸縮振動 $[v(\mathrm{Fe}-\mathrm{His})]$ バンドの発見は, 後述のように, $\mathrm{Hb}$ 研究にブレークス ルーをもたらした16).

\section{2 レチナール}

レチナールを補欠分子族として含むタンパク質を総称し てレチナールタンパク質とよぶ、レチナールは, タンパク 質中で，リシン残基側鎖とシッフ塩基を形成している（図 3). 代表的なレチナールタンパク質には, 視覚の光受容 タンパク質であるロドプシン，光駆動性プロトンポンプで あるバクテリオロドプシン (BR) がある.

Mathies のグループは, オールトランス形, 13-シス形, 11-シス形，9-シス形コンフィギュレーションのレチナー ルについて，エチレン炭素をひとつずつ ${ }^{13} \mathrm{C}$ に置換したも のおよび各 $\mathrm{C}-\mathrm{H}$ を $\mathrm{C}-\mathrm{D}$ に置換したものを合成し，振動 モードの帰属と基準振動解析を行った ${ }^{17)}$. また, タンパ ク質に対しても, 約 20 種類の同位体置換レチナールを BR に再構成し，オールトランス形18) と13-シス形199について 詳細な解析を行った。

レチナールでは，1000-1400 $\mathrm{cm}^{-1}$ の領域に，C-C 伸縮 振動と C-H 面内変角振動が混合した振動モードが現れ る.これらは,レチナールのコンフィギュレーションに大

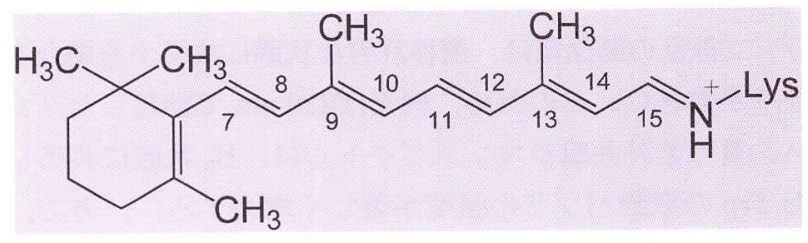

図３レチナールの分子構造. コンフィギュレーションが オールトランス形で, リジンとシッフ塩基を形成した 状態のものを示してある. 
変敏感であり，マーカーバンドとして用いられる，その解 釈は，上記の同位体効果の膨大なデータが基になってい る。例えば, $\mathrm{C}_{12}-\mathrm{H}$ と $\mathrm{C}_{14}-\mathrm{H}$ の面内変角振動が同位相で 混合したモードは， $\mathrm{C}_{13}=\mathrm{C}_{14}$ 部分の構造を敏感に反映す ることが明らかになり，これを基にして BR 反応中間体の コンフィギュレーションが決定された ${ }^{20)} .1650 \mathrm{~cm}^{-1}$ 付近 に現れる $\mathrm{C}=\mathrm{N}$ 伸縮振動は, シッフ塩基のプロトン化状態 を調べるのにしばしば用いられる．軽水中と重水中での同 位体シフトの有無からプロトン化しているか否かが判定で きるためである．また，850-1000 $\mathrm{cm}^{-1}$ に観測されるC$\mathrm{H}$ 面外変角振動は，ポリエン部分の捻じれの程度に敏感 である。

\section{3 芳香族アミノ酸残基}

ラマン散乱の励起波長として，210-250 nm の光を用 いると，芳香族アミノ酸残基の側鎖芳香環の振動モードが 観測される21-23)。側鎖芳香環の電子構造は, ベンゼンお よび一置換ベンゼンのものとよく対応している. ベンゼン の場合，第一許容 $\pi^{*} \leftarrow \pi$ 遷移 $\left(\mathrm{B}_{\mathrm{a}, \mathrm{b}} \leftarrow \mathrm{A}_{1}\right)$ の低エネルギー 側にふたつの遷移禁制の電子状態 $\left(\mathrm{L}_{\mathrm{a}}\right.$ および $\left.\mathrm{L}_{\mathrm{b}}\right)$ がある. 置換により分子の対称性が崩れるために，禁制遷移に遷移 許容性が生じる。これらの電子励起状態への遷移エネル ギーは, 分子の対称性により変化する.このため, ラマン 散乱の励起光を選択することで，タンパク質中の特定部位 にあるこれらの芳香族アミノ酸残基の選択的観測が可能と なる.

Rava とSpiro は, 芳香族アミノ酸のラマンスペクトル の励起波長によるスペクトル形の変化を測定した ${ }^{24)}$ 。そ の結果，観測される紫外共鳴ラマンスペクトルには， $\mathrm{B}_{\mathrm{a}, \mathrm{b}}$ $\leftarrow \mathrm{A}_{1}$ 許容遷移の $\mathrm{A}$ 項による共鳴増強を受ける全対称振動 モードのバンド， $\mathrm{L}_{\mathrm{a}}$ 状態と $\mathrm{B}_{\mathrm{a}, \mathrm{b}}$ 状態との間の振電相互作 用に基づく $\mathrm{B}$ 項による共鳴効果を示すバンドが含まれる ことを示した。 また，呼吸振動モードのバンドが $\mathrm{B}_{a, b}$ 状 態への前期共鳴により強度増大することを明らかにした。

Asher らは，207-270 nm の波長範囲でラマン励起プロフ ィールを測定した ${ }^{25-28)}$. 水溶液中の Tyr および脱プロト ン化により生成するチロシネートの励起プロフィールは $\mathrm{L}_{\mathrm{a}}$ 状態に共鳴したものであり，その極大がそれぞれ 225 $\mathrm{nm}$ および $245 \mathrm{~nm}$ にあることが示された. Trpについて は，遷移許容な $\mathrm{B}_{\mathrm{b}}$ 状態への遷移エネルギーが低下するた め， $\mathrm{B}_{\mathrm{b}}$ 状態に共鳴する励起プロフィールの極大は $224 \mathrm{~nm}$ に長波長シフトすることが報告された。A 項による共鳴 ラマン散乱の断面積は, 遷移許容な状態に共鳴する場合の ほうが大きい，このため，例えば $220 \mathrm{~nm}$ で励起したタン パク質の紫外共鳴ラマンスペクトルは， $\mathrm{B}_{\mathrm{b}}$ 状態に共鳴し た Trp の振動バンドの強度が著しく増大する。一方で, $\mathrm{B}_{\mathrm{b}}$ 状態に共鳴した Trp のラマン励起プロフィールの幅は 約 $20 \mathrm{~nm}$ と狭いため, 例えばより長波長の $240 \mathrm{~nm}$ や，短 波長の $210 \mathrm{~nm}$ の励起波長では, Trpのバンド強度が減少
し，代わって Tyr や Phe のバンドの相対強度が増大する.

芳香族アミノ酸残基の紫外共鳴ラマンスペクトルは, タ ンパク質内における残基周辺の環境変化の指標とな る23). ラマンバンドの振動数については, Trpでは, $1550 \mathrm{~cm}^{-1}$ に現れるW3 バンドがインドール環周辺の二 面角の変化により振動数がシフトする29). Tyrでは, $1620 \mathrm{~cm}^{-1}$ 付近に現れるY $8 \mathrm{a}$ 打よび $\mathrm{Y} 8 \mathrm{~b}$ バンド， 1200 $\mathrm{cm}^{-1}$ 付近に現れる $\mathrm{Y} 7 \mathrm{a}$ バンドの振動数が，ヒドロキシル 基のプロトン供与能や水素結合強度に敏感である. また, $1180 \mathrm{~cm}^{-1}$ 付近に現れる $\mathrm{Y} 9 \mathrm{a}$ バンドの振動数は, 水素結 合強度が増加する場合や，ヒドロキシル基の二面角変化に 対して変化する23,30). また，ラマンバンドの強度について は, Trpでは, W3 バンド, 打よび $1000 \mathrm{~cm}^{-1}, 870 \mathrm{~cm}^{-1}$, $760 \mathrm{~cm}^{-1}$ にそれぞれ現れるW16,W17,W18 バンドが， Tyr では，Y8a，Y9a，および Y7aバンドが，側鎖周囲の 環境変化に応じてその強度を変える。これは，水素結合強 度や疎水性相互作用の変化によって励起プロフィールのシ フトが起こるためで, これらのバンド強度の変化を調べる ことによって，側鎖周囲の環境変化を知ることができ $ろ^{31)}$.

\section{4 ペプチド結合}

タンパク質の主鎖を形成するぺプチド結合 $(-\mathrm{CONH}-)$ は,アミド振動とよばれるいくつかの特徴的な振動モード を示す32-35)。この振動数は，側鎖の構造の影響をほとん ぞ受けず，ポリペプチド主鎖の構造をよく反映する.ペプ チド結合のカルボニル基は，その $\pi-\pi$ 吸収帯を極大波長 $190 \mathrm{~nm}$ 付近にもつ. したがって, ラマン散乱の励起光の 波長をこの吸収帯に合わせると，アミド振動モードや，さ らに $\alpha$ 炭素に結合した水素原子の面内変角振動 $\left(\mathrm{C}_{\alpha}-\mathrm{H}\right.$ bend）モードに起因するラマンバンドが強度増大する. このため, これらのモードのバンド強度や振動数は, タン パク質の二次構造の指標となる. Asher らは，さまざまな タンパク質のアミド振動バンドの共鳴ラマンスペクトルを 測定し, その振動数と強度から二次構造を経験的に決定で きることを示した ${ }^{36)}$.アミド皿バンド抢よび $\mathrm{C}_{\alpha}-\mathrm{H}$ bend バンドのスペクトルは, ポリペプチド鎖のコンフォメーシ ヨン角に特に敏感であり, 二次構造の決定に役立つ37). アミド振動バンドから二次構造決定ができることを利用し て, 温度ジャンプ法を用いた時間分解測定により, タンパ ク質のフォールディングの初期過程を観測する研究が最近 行われている38-40). フォールディング過程は, タンパク 質の機能そのものではないが，タンパク質科学のトピック として興味深い現象であり注目される.

タンパク質の二次構造に関する情報は, 赤外吸収スペク トルや円二色性スペクトルからも共鳴ラマンスペクトルと 相補的に得ることができる。しかし，赤外吸収スペクトル ではアミドI，および而バンドなどはタンパク質の他の振 動モードと重なってしまうため, アミド I バンドの観測以 
外にタンパク質の二次構造変化の議論を行うことは難し い.むた，円二色性スペクトルは，タンパク質試料からの 散乱や発光によりバックグラウンドのふらつきが大きくな るため, 測定に困難さがある。これに対して, 共鳴ラマン スペクトルは上記の妨害を受けにくい，この点は，タンパ ク質の二次構造変化を観測するうえで，ラマン分光法の優 れているところである。

\section{3. 時間分解共鳴ラマン測定の実際}

\section{1 時間分解測定の原理}

タンパク質が機能する仕組みを理解するには，機能する 過程の動的情報を得ることがきわめて重要である。なかて も，反応中間体の構造を同定することは，反応機構の解明 に直結する．タンパク質の反応においてはピコ秒から秒の 時間領域にわたって反応中間体が生じるため, これらの領 域において構造情報が求められねばならない，共鳴ラマン 分光法は NMR 分光法や $X$ 線回折法に比べて高い時間分 解能を持つので，時間分解測定によって構造情報を幅広い 時間領域で求めることができる. 通常, 時間分解共鳴ラマ ン測定を行うには主に次の 2 種類の方法がある.

\subsection{1 フロー法（マイクロ秒〜秒の時間領域）}

マイクロ秒〜秒の時間領域であれば，フロー法を用いて $\mathrm{CW}$ 光レーザーで時間分解測定を行うことができる. タン パク質試料の測定に関しては，レーザー光による損傷を防 ぐために, 単位時間当たりの光子数をできるだけ低くした ほうがよい，そのため，パルスレーザーを用いるよりも CWレーザーを用いるほうが試料への影響が少ない，混合 フロー法では, 混合点からの距離および流速を調節するこ とによって，サブミリ秒〜秒の時間領域の時間分解共鳴ラ マンスペクトルを測定することができる。これは $2 つ の$ 容器の片方にタンパク質溶液, もう片方に基質を含んだ緩 衝液を準備し，これらの液を高速で流し，急速に混合させ る. 混合フロー法では従来不感時間が数ミリ秒あり，これ が時間分解能の限界となっていた．最近装置の改良によっ て不感時間が $11 \mu \mathrm{s}$ まで改善され，蛍光強度からサブミリ 秒領域のタンパク質の折れたたみダイナミクスが調べられ ている41). 光によって開始される反応（ケージド化合物 を利用する場合を含む）では，2 種類の CW 光を用いた ダブルビーム法による時間分解測定が可能である. この方 法では試料を一定速度でフローセルに流し，反応を開始す るためのレーザー光を上流側に，共鳴ラマンスペクトルを 測定するためのレーザー光を下流側にセットする．流速と 2 つのレーザー光の間隔を調節し, 望みの遅延時間を設定 する，通常のガラスキャピラリーを使った場合, 遅延時間 の下限は $10 \mu \mathrm{s}$ 程度であり，これは流速の上限から決まっ ている. 最近の進展として，ガラス表面に彫った深さ 42 $\mu \mathrm{m}$, 幅 $142 \mu \mathrm{m}$ の溝に試料を流し， $250 \mathrm{~ns}$ の時間分解能 を得たという例42)を挙げることができる.ダブルビーム
法を使った研究として，Ogura，Kitagawa らによるチト クロム酸化酵素の $\mathrm{O}_{2}$ 活性化機構に関する研究 ${ }^{43)}$ (後述), Mathies らによる BR，ロドプシンの光による活性化機構 に関する研究がある. BR では， $\mathrm{J} \rightarrow \mathrm{K} \rightarrow \mathrm{L} \rightarrow \mathrm{M} \rightarrow \mathrm{N} \rightarrow \mathrm{O}$ と いう中間体を経て光反応サイクルが進行するが，このうち L 中間体から $\mathrm{O}$ 中間体のレチナール部位の構造がこの方 法によって決定された ${ }^{44-47)}$. また，ロドプシンに関して もバソー，ルミー，メタ中間体についての報告がある42).

3.1.2 パルスレーザー法（ピコ秒〜ミリ秒の時間領域）

マイクロ秒より短い時間領域で時間分解共鳴ラマンスペ クトルを測定するにはパルスレーザーを用いる．タイミン グシッターの関係から，ピコ秒〜ナノ秒，ナノ秒〜ミリ秒 の時間領域で方式が異なるのでそれぞれ分けて説明する. ピコ秒〜ナノ秒の時間領域を調べるには, ピコ秒のパルス 光源が必要である. この場合, 1 台のパルスレーザーの出 力から発生させた, 反応開始用のパルス光 (ポンプ光), および共鳴ラマン測定用のパルス光（プローブ光）を用い る. 片方のパルス光を, 光学遅延路を経由して, もう一方 のパルス光と空間的に重ねて試料に照射する. 時間分解能 はパルス幅によって決定されるが，通常エネルギー分解能 （波数分解能）を失わないよう数ピコ秒のパルスが用いら れる. 一方, 最長の遅延時間は光学遅延路の長さによって 決定され, 通常数ナノ秒, 長くともせいぜい $10 \mathrm{~ns}$ 程度で ある。これ以降の時間領域を調べるには，2台のナノ秒 レーザーを用い, 片方でポンプ光を発生させ, もう片方で プローブ光を発生させるやり方が一般的である. 2 つのパ ルス光の照射タイミングはデジタルパルス発生器で制御す る. 時間分解能はレーザーのパルス幅によって決定され， 遅延時間の上限はパルスの繰り返し周期によって決まる.

\section{2 実験装置}

タンパク質部分の構造ダイナミクスの検出には, 得られ たラマンバンドの微小な変化を解析する必要があるので, 測定の高感度化が不可欠である. 筆者らは，そのために， ラマン散乱の励起光として可視領域および紫外領域の波長 を用いる，ふたつの独立したピコ秒時間分解共鳴ラマン分 光システムを開発した. 時間分解可視共鳴ラマン分光シス テムの詳細については他の文献 ${ }^{48)}$ に譲り, 本稿では, 最 近，筆者らが製作・改良を行ってきたピコ秒時間分解紫外 共鳴ラマン分光システムについて紹介する.

図 4 にシステムの概略図を示す．このシステムの特徵 は，種々の波長変換技術を用いて多様な波長の光を選択 し, 補欠分子族の光励起により誘起されるタンパク質部分 の構造ダイナミクスをピコ秒の時間分解能で高感度に検出 できる点である．概要は以下のとおりである．光源には， 繰り返し $1 \mathrm{kHz}$ のピコ秒チタンサファイア再生増幅シス テムを用いている，レーザー出力の第二高調波（389-410 $\mathrm{nm}$ ）を二つに分割し，種々の非線形光学効果による波長 変換を行って, 調ベたいタンパク質に最適な波長のポンプ 


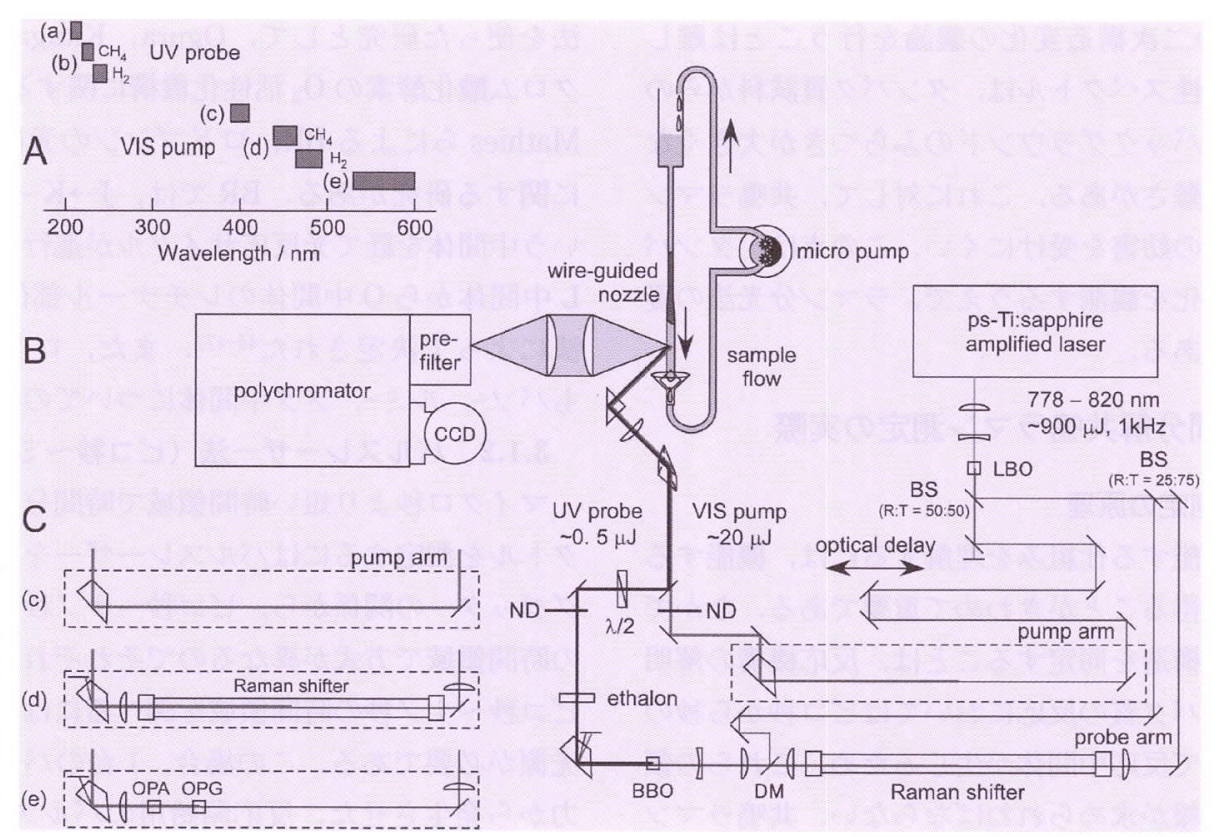

図 4 ピコ秒時間分解紫外共鳴ラマン分光システム A : ポンプ光およびプローブ光の波長範囲. B : 装置の概略図. C : ポンプ光の発生方法. (a), (b) : 紫外プローブ光, (c), (d), (e) : 可視ポンプ光. $\mathrm{LBO}=$ 四ホウ酸リチウム $\left(\mathrm{Li}_{2} \mathrm{~B}_{4}\right.$ $\left.\mathrm{O}_{7}\right)$ 結晶, $\mathrm{BBO}=$ ベータホウ酸バリウム $\left(\beta-\mathrm{BaB}_{2} \mathrm{O}_{4}\right)$ 結晶, $\mathrm{BS}=$ ビームスプリッター, $\mathrm{DM}=$ ダイクロイックミ ラー, $\mathrm{ND}=\mathrm{ND}$ フィルター。

光抢よびプローブ光を十分な強度で得る．これらの光をタ ンパク質試料溶液に集光し, 試料からのラマン散乱光を主 分光器により分散し, $\mathrm{CCD}$ 検出器によって検出する. 試 料からの光のうち, レイリ一散乱光や蛍光成分は, 主分光 器の前に取り付けたプリズム分散型分光器により除去して 扔く.このようにして, 光反応によるタンパク質部分の構 造変化を，紫外プローブ光によるスペクトル変化から観測 する，以下に，本測定の留意点を項目ごとにまとめる.

\subsection{1 紫外プローブ光·可視ポンプ光}

タンパク質の紫外共鳴ラマンスペクトルの变化を高感度 で観測するためには，補欠分子族やタンパク質部分におけ る観測部位の電子吸収带がある波長に, プローブ光および ポンプ光の波長を合わせる必要がある。筆者らはさまざま な非線形光学効果を用いてこれを実現した。

タンパク質部分の個々の部位における振動モードを, 共 鳴ラマン効果を利用して選択的に観測するには, プローブ 光を紫外波長領域で広範かつ連続的に得なければならな い.このため, プローブ光発生用の光を, 高圧のメタンガ スまたは水素ガスを封入したラマンシフタに集光し, 誘導 ラマン散乱を発生させた後, 1 次ストークス誘導ラマン散 乱光とレーザー光第二高調波の和周波発生（メタン：206 $-218 \mathrm{~nm}$, 図 4A(a)), 拈よび1次ストークス誘導ラマン 散乱光の第二高調波発生（メタン: 219-233 nm，水素： 232-247 nm, 図 4A(b)) の二通りの方法で, 波長206$247 \mathrm{~nm}$ の範囲にわたって充分な強度 $(\sim 0.5 \mu \mathrm{J})$ で得て いる、タンパク質の構造ダイナミクスを詳細に議論するた めには，スペクトル測定に，少なくとも $10 \mathrm{~cm}^{-1}$ 程度の波
数分解能が必要である.これを実現するために, 波長变換 に誘導ラマン散乱 ${ }^{49)}$ を用いているほか, 光路上にエタロ ンを配置し，エネルギ一幅を小さくしている。

光反応によるスペクトル変化の検出効率を向上させるた めに，ポンプ光の波長を観測対象のタンパク質の補欠分子 族の吸収極大付近になるよう調整する。そのため, レー ザー出力の第二高調波（389-410 nm，図 4A(c)) のほか に，メタンガス抢よび水素ガスのラマンシフタの 1 次ス トークス誘導ラマン散乱光 (メタン: 439-465 nm, 水素 : 464-494 nm, 図 4A(d) ) 打よび光パラメトリック発生 · 増幅光 (530-600 nm, 図 4A(e)) を使用している。これ により, ポンプ光は可視光のほぼ全波長領域をカバーする ことができ，さまざまなタンパク質（例えば，へムタンパ ク質，イエロープロテイン (PYP), レチナールタンパク 質, 抢よびフラビンタンパク質など）の光応答による構造 変化の高感度追跡が可能である.

ピコ秒時間分解ラマン測定における, 光パルスの時間幅 とエネルギー幅の間には, フーリエ変換限界とよばれる関 係があり，両者の積には下限值がある。したがって，2つ の幅を独立に極限まで狭めることはできない，エネルギー 幅 $10 \mathrm{~cm}^{-1}$ の光パルスでは, 時間幅の下限值は約 $1 \mathrm{ps}$ で ある. 本システムの時間分解能は, ポンプ光とプローブ光 の相互相関時間が約 $3 \mathrm{ps}$ であることから, 振動スペクト ルの時間分解測定において, 時間およびエネルギー分解能 の組み合わせは極限に近いといえる。

ピコ秒パルスの場合, 試料に照射される光電場は非常に 大きい，このため，使用する光の強度には十分な注意が必 
要である. 例えば，プローブ光の強度が大きすぎると，プ ローブ光強度とラマン散乱強度の線形性が崩れる, いわゆ る「飽和現象」が起きる. また, 強いプローブ光による光 反応で副生成物が生成し，そのスペクトルが観測されるこ とがある ${ }^{25,27)}$.このようなことが起こると, 正しいダイナ ミクス観測が不可能になる.これを避けるためには, 測定 前に実験条件を十分に検討し, NDフィルター等による光 強度の調節が必要である。

\section{2 .2 タンパク質試料}

ラマン分光法は, 試料の形態による測定の制限が少な く，目的に合わせてこれを選択できる. タンパク質のラマ ンスペクトル測定においても例外ではなく, 生体内に近い 環境で質のよいスペクトルを得ることができる.これは他 の分光法にはない利点である. 例えば， BRなどの膜タン パク質では，懸濁した膜断片溶液を測定するが，このよう な状態でも $\mathrm{S} / \mathrm{N}$ 比のよいスペクトル測定が十分可能であ る.

パルスレーザーを用いた時間分解共鳴ラマン測定では, パルスごとに光反応に対してフレッシュな試料への光照射 を常にしなくてはならない，また，レーザー光を試料の同 じ部分に照射し続けると, 試料が光を吸収し, 局所的な温 度上昇や, 光強度が高い場合には誘電破壊で劣化する.こ のため, 液体試料をフローさせる必要があり, 回転セルや フロー装置を用いている. 回転セル装置は, 円筒形のセル に試料を入れ高速回転させることで, 常に光照射体積内の 試料が新しくなるようにすることができる，筆者らは，外 径 $10 \mathrm{~mm}$ の NMR チューブを長さ $50 \mathrm{~mm}$ に切断し, これ をアルミ製のホルダーに挿入し，ブラシレス DC モーター に取り付けている. 気密性が求められる試料や，ごく少量 （1 mL 程度）の試料を測定する場合に便利である. 一方, フロー装置は, マイクロポンプやペリスタポンプを用いて 送液を行う、筆者らが使用しているフロー装置（ワイヤガ イドノズル法50)）の概略を図 4 中に示す。上部の液溜め にある試料は, 重力により 2 本のワイヤ間を落下し均質 な液膜を形成する。下部に流れた溶液は，マイクロポンプ により送液され，再び液溜めに戻る．溶液の循環により， 少量のタンパク質試料の繰り返し測定を行うことができ る.この装置の光照射面にはガラスセルや石英セルがない ため, エネルギーが高いピコ秒パルス光を用いる測定に適 している. また, 液膜の厚さは 100-500 $\mu \mathrm{m}$ 程度に調節で きるので, 試料中の光路長が短くなり, 紫外波長領域の夕 ンパク質の強い吸収による共鳴ラマン散乱の自己吸収効果 を小さく抑えられる利点がある。

\section{2 .3 ラマン散乱光の検出}

良質な時間分解共鳴ラマンスペクトルを得るためには, 試料からのレイリ一散乱光や蛍光などの迷光を最大限に除 去し, ラマン散乱光の強度ロスをできるだけ最小限にとど める必要がある. 可視共鳴ラマン測定では, ラマン散乱光
を分散するシングル分光器の入射スリットの直前に，ノッ チフィルターやバンドパスフィルターなどの光学フィル ターを配置して, 迷光除去を行っている. 一方, 紫外共鳴 ラマン測定の場合, ラマン散乱光のみが効率よく透過する 光学フィルターがないため, これを用いた迷光除去は困難 である.このため，リトロープリズムを用いた前置分光 器51)を主分光器の直前に配置し, プレフィルターとして 使用している. この分光器の透過率は, グレーティングを 使用していないため約 $60 \%$ と高く，より高強度のラマン 散乱光を主分光器へ導入することが可能である. 前置分光 器と主分光器の $\mathrm{F}$ 值は3.5-4.0 と小さく, またこれらの間 の F マッチングが良好であることから，より多くのラマ ン散乱光を CCD 検出器に到達させることができる. 主分 光器は, 得られるラマンスペクトルの波数分解能を高くす るため, 本システムでは, 焦点距離 $500 \mathrm{~mm}$ のシングル分 光器において, グレーティングの刻線数が $2400 \mathrm{gr} / \mathrm{mm}$ (ブレーズ波長 $250 \mathrm{~nm}$ ), または $1200 \mathrm{gr} / \mathrm{mm}$ （ブレーズ波 長 $500 \mathrm{~nm} ）$ のものを使用し，それぞれ 1 次および 2 次回 折光を CCD 検出器で検出している.

紫外共鳴ラマンスペクトルの測定には, CCD 検出器の 量子効率も考慮し適切なものを使用する必要がある. 分光 用の CCD 素子には, 光の照射面に対して酸化シリコン製 の電極が表面にある表面照射型 CCD と裏面に配置された 背面照射型 CCD の 2 種類がある. 酸化シリコンは被測定 光を透過させにくいため, 量子効率は背面照射型 $\mathrm{CCD}$ の ほうが高い。さらに素子上に観測波長に合わせた反射防止 コーティングを施すことで, 紫外光領域で量子効率を最大 で70\%程度まで向上することが可能である。ただし，反 射防止コーティングをした場合, 最適波長以外では量子効 率が著しく低下するため, 素子の選択は装置の仕様に合わ せて考慮する必要がある52).

\section{4. 連動性が生み出すタンパク質の機能}

\section{1 連動性による協同性発現}

\subsection{1 ヘモグロビン, ミオグロビン}

$\mathrm{Hb}$ の協同性は, 構造変化が機能発現に強く関わってい る典型例である. $\mathrm{O}_{2}$ 運搬体である $\mathrm{Hb}$ は, 生命活動に重 要なタンパク質であること, また比較的容易に大量のタン パク質試料が得られることから, 多くの分子科学研究がこ れまでに行われている. なかでも, 共鳴ラマン分光法によ る研究は協同性発現機構の理解に大きな貢献を果たしてき た.ここでは，その代表的な研究を紹介する.

$\mathrm{Hb}, \mathrm{Mb}$ ともに, 鉄の軸配位座にはヒスチジン（His） のイミダゾール環が配位している（この His 残基を近位 His とよぶ). そのトランス位に $\mathrm{O}_{2}$, 一酸化炭素 $(\mathrm{CO})$, 一酸化窒素 (NO) といった二原子分子が結合する.へム が可視光を吸収するとこれら二原子分子は解離するので, この光反応を利用して, $\mathrm{O}_{2}$ 結合部位からリガンドが解離 
する際にタンパク質がどのように応答するかを調べること ができる ${ }^{53)}$. リガンドの光解離は数百フェムト秒以下と 非常に速く起きるため，これを構造変化のスタートトリ ガーとして利用する. $\mathrm{Hb}, \mathrm{Mb}$ の生理的なリガンドは $\mathrm{O}_{2}$ であるが, 光解離反応の收率が高いこと, 解離したリガン ドの再結合が遅いことなどの理由から，CO をリガンドと して用いた実験が非常に多く行われている.

a) へムの構造変化

リガンド結合状態では鉄はポルフィリン面にあるが，リ ガンドがはずれた状態（デオキシ形）では鉄がポルフィリ ン面より近位 His 側に約 $0.3 \AA$ 出ていて, ポルフィリン面 がドーム形に変形していることがX 線結晶解析より報告 されている54)。これは，デオキシ形では，へム鉄が高ス ピン状態になり，ピロール窒素との反発が大きくなり，平 面から押し出されるためである。リガンド脱着に伴うこの ようなへムの变形と鉄原子の変位は, タンパク質構造の変 化を誘起する．これが Hbにおいて四次構造変化を引き起 こす最初の動きであると考えられている。そのため，平面 型からドーム型への変形がどれくらいの速さで起きている かに興味が持たれた。

Franzen らは, $\mathrm{Hb} の \mathrm{CO}$ 光解離に伴うピコ秒時間分解 共鳴ラマンスペクトルを報告した ${ }^{55)}$ 。彼らは，へムの面 内伸縮振動モードの振動数がデオキシ形のそれらとほぼ一 致することから, CO 解離後のへムのドーム型への変形は きわ女て速く起きると結論した， Mbについても， CO 光 解離後のピコ秒時間分解共鳴ラマンスペクトルが筆者らに よって報告された ${ }^{56,57)}$. 図 5 に CO 結合形 $\mathrm{Mb}$ のピコ秒時 間分解可視共鳴ラマンスペクトルを示す. 2.1節で述べた ように，可視光をプローブ光とした Mbの共鳴ラマンス ペクトルには，へム由来の振動バンドが観測される. 図中 のスペクトルは実測スペクトルから未反応分の CO 結合形 のスペクトルを差し引いた差スペクトルとして表してあ り，左側の数字は遅延時間を表す。 0 ps を境にしてプラ スの時間帯では反応生成物（すなわち解離形へム）のラマ ンバンドが現れているのがわかる。をた，デオキシ形と $\mathrm{CO}$ 結合形のスペクトルを比較のため下に示してある. $1000 \mathrm{ps}$ のスペクトルでは 4 本の面内振動（ $v_{5}, 1119$ $\left.\mathrm{cm}^{-1} ; v_{4}, 1355 \mathrm{~cm}^{-1} ; v_{2}, 1563 \mathrm{~cm}^{-1} ; v_{10}, 1619 \mathrm{~cm}^{-1}\right)$ が観 測されており，デオキシ形のスペクトルと誤差範囲内で一 致する。これらのバンドは 0 psから現れておりへムの 構造変化のほとんどが装置の時間分解能以下で非常に速く 起っていることを示している．０から10 psの間では中心 波数やバンド幅に変化がみられるが，これらの変化は CO 解離直後の反応余唾エネルギーが散逸する過程によるもの である56)

b) $\mathrm{Fe}$-His 結合の変化

$\mathrm{Hb}, \mathrm{Mb}$ ともにリガンド解離に伴うへムのドーム型へ の変形はサブピコ秒で起きることがわかった。では，この

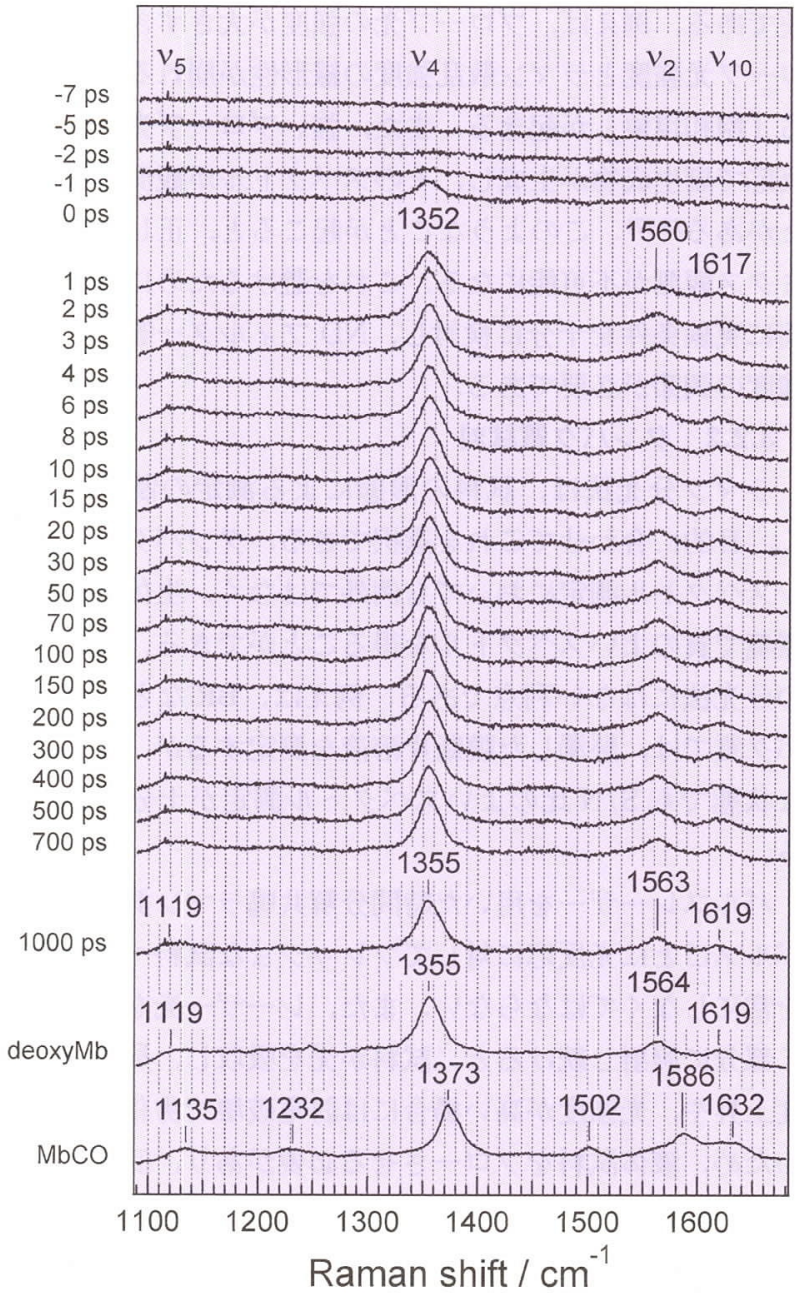

図 $5 \mathrm{CO}$ 結合形ミオグロビンの光解離についての時間分解 可視共鳴ラマンスペクトル. 1100 から $1700 \mathrm{~cm}^{-1}$ の 波数領域を示す，比較のため，デオキシ形， CO 結合 形の共鳴ラマンスペクトルをあわせて示す。

へムの構造変化に対して, タンパク質部分の構造はどのよ うに応答するのだろうか。このとき理解の鍵となるのは, ヘムとタンパク質をつなぐ部分，すなわちへムの軸配位子 である近位 His である.

近位 His は, Hbの機能にとっても, 重要な役割を果た している. $\mathrm{Hb}$ の協同性発現は， $\mathrm{O}_{2}$ 親和性の異なる 2 種類 の四次構造の間の平衡を考えるモデルで説明されている.

$\mathrm{Hb}$ は 1 分子あたり 4 か所の $\mathrm{O}_{2}$ 結合部位をもっている が，これらへの $\mathrm{O}_{2}$ 結合数が多くなるほど，平衡が， $\mathrm{O}_{2}$ 親 和性が低い構造 ( $\mathrm{T}$ 構造) から $\mathrm{O}_{2}$ 親和性が高い構造 ( $\mathrm{R}$ 構造）へと傾くと考えると, 協同的な $\mathrm{O}_{2}$ 親和性を定量的 に説明できる。これはモデルとしてはよく理解されている が， $\mathrm{T}$ 構造と $\mathrm{R}$ 構造の， $\mathrm{O}_{2}$ 親和性を生み出す構造上の違 いは長い間不明であった。1962年に「球状タンパク質の 構造研究」でノーベル化学賞を受賞した, Max F. Perutz は,「四次構造の違いによって, タンパク質からの張力が 鉄一近位 His ( Fe-His) 結合を通してへムに伝わり， $\mathrm{O}_{2}$ 親 和性が制御されている」という仮説を提案した，このモデ 
ルに対しては, Kitagawa らによって， $\mathrm{O}_{2}$ 親和性が低いも のほど $v$ (Fe-His) 振動数が低い,すなわち Fe-His 結合 が弱い（張力が強い）という相関関係が見いだされ，その 妥当性が証明された ${ }^{58)}$ 。これは, 化学結合の変化がタン パク質機能において重要な役割を果たすことを，共鳴ラマ ン分光法を使って示した好例である.この発見は，その後 の, $v(\mathrm{Fe}-\mathrm{His})$ バンドを用いた $\mathrm{Hb}$ 高次構造研究のブレー クスルーとなった.

$v(\mathrm{Fe}-\mathrm{His})$ 振動数が $\mathrm{Hb}$ の四次構造によって異なると いうことから, 高次構造変化のプローブとして, リガンド 解離に伴って振動数がどのように時間変化するかに興味が もたれた. Friedmanらは，一波長の光パルスによる過渡 種の測定を行った。いわばこれは, ひとつのパルスがポン プパルスとプローブパルスの役割を兼ねるもので, パルス 幅内の時間平均の情報が得られる. Findsen らは, この方 法を使って, $25 \mathrm{ps}$ と $10 \mathrm{~ns}$ のパルスで, 光解離過渡種の 共鳴ラマンスペクトルを測定した. $\mathrm{Hb}$ では, $25 \mathrm{ps}$ パル スと $10 \mathrm{~ns}$ パルスでは振動数に差はほとんどなく約 230 $\mathrm{cm}^{-1}$ で, これらはデオキシ形の值約 $215 \mathrm{~cm}^{-1}$ に比べ高 かった ${ }^{59)}$.これに対して, $\mathrm{Mb}$ では, 三者の間にほとんど 差はなかった ${ }^{60)}$. このことから $\mathrm{Hb}$ の高次構造変化は 10 ns 以降に起きることが結論された. その後, Friedman ら は，2台のナノ秒パルスレーザーを組み合わせて， $v(\mathrm{Fe}-$ His）振動数の時間变化を測定し， $10 \mathrm{~ns}$ から $10 \mu \mathrm{s}$ をで の, 連続的な振動数変化を観測している61).

筆者らは, $\mathrm{Mb}$ でピコ秒領域の $v(\mathrm{Fe}-\mathrm{His})$ 振動数変化 を高精度で調べた。その結果, このバンドは, 解離直後 $222 \mathrm{~cm}^{-1}$ に現れ, 約 $100 \mathrm{ps}$ の時定数でデオキシ形の值 $220 \mathrm{~cm}^{-1}$ へ緩和することが明らかになった ${ }^{57)}$. 対照実験 の結果から，これは数ピコ秒以下のへムの構造変化によっ て生じたへム周囲の歪みがタンパク質構造の緩和とともに 解消されていく過程を反映していると帰属された。この振 動数シフトは, Friedman らの測定ではシフト量が小さく 検出されなかったが, 筆者らの, 高い $\mathrm{S} / \mathrm{N}$ 比のスペクト ル測定によって初めて見出されたものである.

c）タンパク質の構造変化

$\mathrm{Hb}$ の 2 種類の四次構造では, サブユニット界面の相互 作用が大きく異なっている. すなわち, $\mathrm{R}$ 構造では, サブ ユニット間に多くの水素結合, 塩橋が形成されているのに 対し， $\mathrm{T}$ 構造ではこれらの相互作用がほとんど切断され ていることがX 線結晶構造解析, NMRを用いた研究か ら明らかにされている62). リガンド脱着に伴うサブユニ ット界面の時間変化をリアルタイムでモニターできれば, 四次構造遷移メカニズムの理解が大きく進む. Kaminaka らは, 時間分解紫外共鳴ラマン分光法を用いて, Trp 残基 のスペクトルから，サブユニット界面の構造変化が $10 \mu \mathrm{s}$ の時間帯で起きていることを明らかにした ${ }^{63)}$.この研究 は，補欠分子族の変化によるタンパク質の構造変化を振動
分光法で初めて時間分解観測したものであり.タンパク質 ダイナミクスの研究として大変大きな意義をもっている.

紫外共鳴ラマンスペクトルの測定において, 高いパルス エネルギーのパルスでは, 芳香族アミノ酸残基が光反応に よって損傷を受けることが指摘されている25,27).90年代前 半では, 紫外共鳴ラマン測定に用いられたパルスレーザー

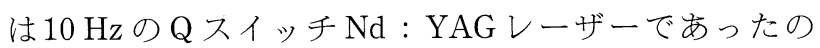
で，パルスエネルギーを低く保つと平均パワーが低くなっ てしまい， S/N 比の高いスペクトルを得るのは困難であ った. Spiroらは，エキシマレーザー励起の色素レーザー を用いて，ナノ秒可視パルスを発生させ，この第二高調波 として高繰り返し $(1 \mathrm{kHz})$ のナノ秒紫外パルスを得た.

これを用いて, $\mathrm{S} / \mathrm{N}$ 比の高い紫外共鳴ラマンスペクトル を得て, それらをもとに Hbのリガンド解離後に起きるサ ブュニット内の変化抢よびサブユニット界面の変化を明ら かにした ${ }^{64)}$. Spiro らによる一連の研究によると，CO 解 離後へムを挟むように存在する 2 本のへリックスが時定 数65 ns で変位し，つづいてサブユニット界面の蝶番領 域, スイッチ領域とよばれる部位の構造変化がそれぞれ時 定数 $2.9 \mathrm{~ns}, 21 \mu \mathrm{s}$ で起きる ${ }^{65)}$.

$\mathrm{Mb}$ についても，へムの構造変化に対するタンパク質の 構造応答に興味がもたれた。 $v(\mathrm{Fe}-\mathrm{His})$ バンドの振動数 変化がサブナノ秒で起きることから, タンパク質の高次構 造変化を観測するためにはピコ秒の時間分解能をもつ紫外 共鳴ラマン分光測定が必要であることが予想される.ナノ 秒時間分解紫外共鳴ラマン分光測定の技術は 90 年代半ば にほぼ確立していたのに対し，ピコ秒時間分解紫外共鳴ラ マン測定の技術確立は，最近まで不十分であった．タンパ ク質のピコ秒時間分解紫外共鳴ラマンスペクトルの最初の 報告は, Kimらによってロドプシンについてなされ た66). 筆者らもこれと独立に同時期に，3.2節に述べたよ うな安定なピコ秒紫外パルス光源と高感度の検出系を開発 し，Mbのダイナミクス研究に適用した ${ }^{67,68)}$.

$\mathrm{Mb}$ の CO 光解離に伴うピコ秒時間分解紫外共鳴ラマン スペクトルを図 6 に示す。1 番上に示したスペクトルは $\mathrm{CO}$ 結合形のスペクトルである.このプローブ光波長で は, 共鳴効果によって Trp および Tyr 残基のラマンバン ドが主に観測されている．COの解離に伴うスペクトル変 化は小さいため, 時間分解スペクトルから CO 結合形のス ペクトルを $1: 1$ で差し引いた差スペクトルとして示して いる．負の遅延時間では差はないが，0ps を境にして差 スペクトルに負のバンドが現れていることがわかる．これ は, $\mathrm{CO}$ 結合形に比べ, 過渡種のラマンバンド強度は小さ いということに対応している. Trp残基のW3, W16, W18バンドとTyr 残基の Y $8 \mathrm{a}$ バンドに扔いて, ピコ秒か らナノ秒の領域における段階的な強度変化が観測された.

$\mathrm{CO}$ 解離後, 装置応答（相互相関時間 $3.3 \mathrm{ps）にほとんど}$ 遅れることなくTrpとTyr残基のバンドは強度減少を示 


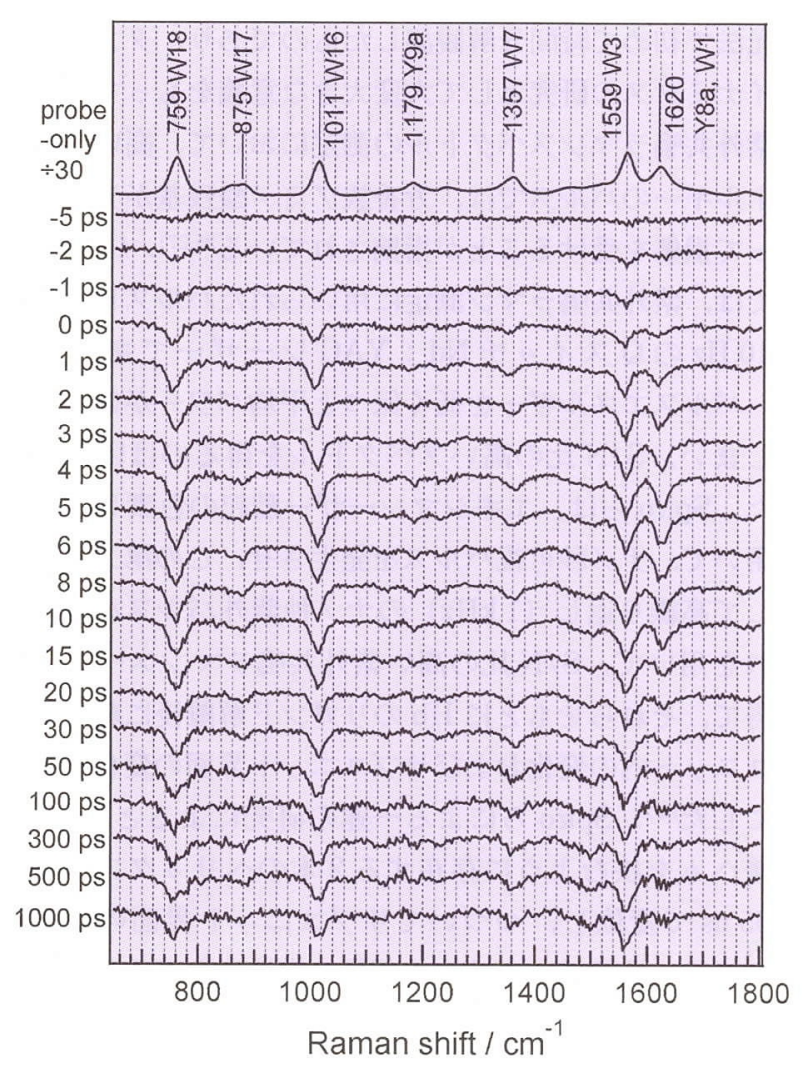

図6CO 結合形ミオグロビンの光解離についての時間分解 紫外共鳴ラマンスペクトル. 650 から $1850 \mathrm{~cm}^{-1}$ の波 数領域を示す. 一番上に, プローブ光のみを照射して 測定した，CO 結合形ミオグロビンの紫外共鳴ラマン スペクトルを示している(ただし, 強度は30で割って ある)。一番下は, デオキシ形のスペクトルからCO 結合形のスペクトルを引いたものである.

し, 続いて $50 \mathrm{ps}$ 程度でY8aバンドの強度が回復した $\left(1620 \mathrm{~cm}^{-1}\right.$ のバンド強度のうち, W1 バンドの寄与は小 さい). Trp 残基のバンドは初期の強度減少の後, ピコ秒 の時間領域では大きくは変化せずナノ秒以降に強度の回復 を示した，実験に用いたウマ由来の Mbには，Trp 抢よ び Tyr 残基がそれぞれ 2 残基ずつ含まれている. Trp を 1 残基しか含まない人工变異体を用いた比較実験の結果，お よび結晶構造から，そのうち，Trp14扔よびTyr146がこ れらのスペクトル変化に主に寄与していると帰属され た ${ }^{67}$. さらに, スペクトル変化は $\mathrm{Hb}$ の場合と同様にへム を挟むように位置する 2 本のヘリックスの動きに対応ゔ けられた。帰属の詳細は原論文 ${ }^{67,68)}$ を参照いただきたい。 重要な点は, この差が装置応答にほとんど遅れることなく 現れたということである.このことはリガンドの解離に対 してこれらのへリックスの動きが非常に速く起きていると いうことを意味する。これは，Hbで対応する動きが $10 \mathrm{~ns}$ の時間帯で起きるのとは対照的である.

可視および紫外共鳴ラマン分光の結果から明らかになっ た $\mathrm{Hb}$ 抢よび $\mathrm{Mb}$ の構造ダイナミクスの描像は次のと扔り である.リガンドの解離に伴ってへム鉄は低スピン形から
高スピン形へ変化する．これによってへムの構造は平面形 からドーム形へ変化する。これらの変化は $2 \mathrm{ps}$ 以内に完 了する．この点は， $\mathrm{Hb}, \mathrm{Mb}$ 共通している. $\mathrm{Mb}$ では, へ ムを上下からはさむように位置するへリックスもへムの構 造変化にほとんど遅れなく追随して応答するのに対し， $\mathrm{Hb}$ ではこの動きに10ns オーダーの時間がかかる，Hbで は，ひきつづきマイクロ秒の時間带でサブユニット界面の 構造変化が起きる。

最近の筆者らの研究から $\mathrm{Hb}$ に特有にみられるナノ秒領 域のダイナミクスは, リガンドの種類, 四次構造の種類と いう Hbにとって重要なパラメータに依存することが明ら かになった，したがって，この相は $\mathrm{Hb} の$ 単なる性質では なく、その機能にとって重要な意味をもっていると考えら れる、詳しくは最近の総説を参照されたい48)、このよう な構造ダイナミクスの特徵が $\mathrm{Hb}$ の機能に具体的にどのよ うに関わっているのかを明らかにすることが今後の課題で ある。

\section{2 連動性による情報伝達}

\subsection{1 へム含有ガスセンサータンパク質}

1992年, NO が Science 誌の Molecule of the Year に選 ばれた69)。こ机は，これをで生物にとって有害なガスと しての認識しかなかった NOが，生体内で制御因子とし て働いていることが明らかになったためである。そ後， NO 以外にもさまざまなガス分子がシグナル分子として機 能し, さまざまな生理機能の制御に関係していることが明 らかになってきた．これは，ガス分子の新規の機能として 注目されている，さらに，ガス分子をシグナルとして検知 するセンサータンパク質のながはへムタンパク質がある ことがわかってきた。これらのタンパク質では，へムとガ ス分子が結合, 解離することで生理機能の制御が行われ る.これは, タンパク質中で, へムと生理機能の活性部位 とが連動することによって, 構造変化を介し, シグナル情 報が伝達される，というように連動性が生み出す情報伝達 の例ととらえることができる。この節では，いくつかのガ スセンサータンパク質の研究例を紹介する.

\section{a) FixL}

FixL は根粒菌由来の $\mathrm{O}_{2}$ センサーへムタンパク質で, $\mathrm{N}$ 末端側のへムを含むセンサードメインと，C 末端側のキ ナーゼドメインからなる ${ }^{70)}$. 高 $\mathrm{O}_{2}$ 濃度条件ではへムは $\mathrm{O}_{2}$ 結合形になりキナーゼ不活性で, 低 $\mathrm{O}_{2}$ 濃度条件では $\mathrm{O}_{2}$ 解離形々なりキナ一ゼ活性となる.FixL の機能発現機構 を理解するためには, リガンドの脱着に伴ってどのような 構造変化が誘起されるのかを明らかにすることが重要であ る、筆者らは, 全長タンパク質扔よびセンサードメインに ついて, 時間分解共鳴ラマン分光法を用いて, $\mathrm{O}_{2}$ 抢よび $\mathrm{CO}$ 解離に伴うへムの構造ダイナミクスを調べた ${ }^{71}$ 。時間 分解共鳴ラマンスペクトルには, いくつかのラマンバンド について強度変化が観測された。 それらの時間変化を図 7 

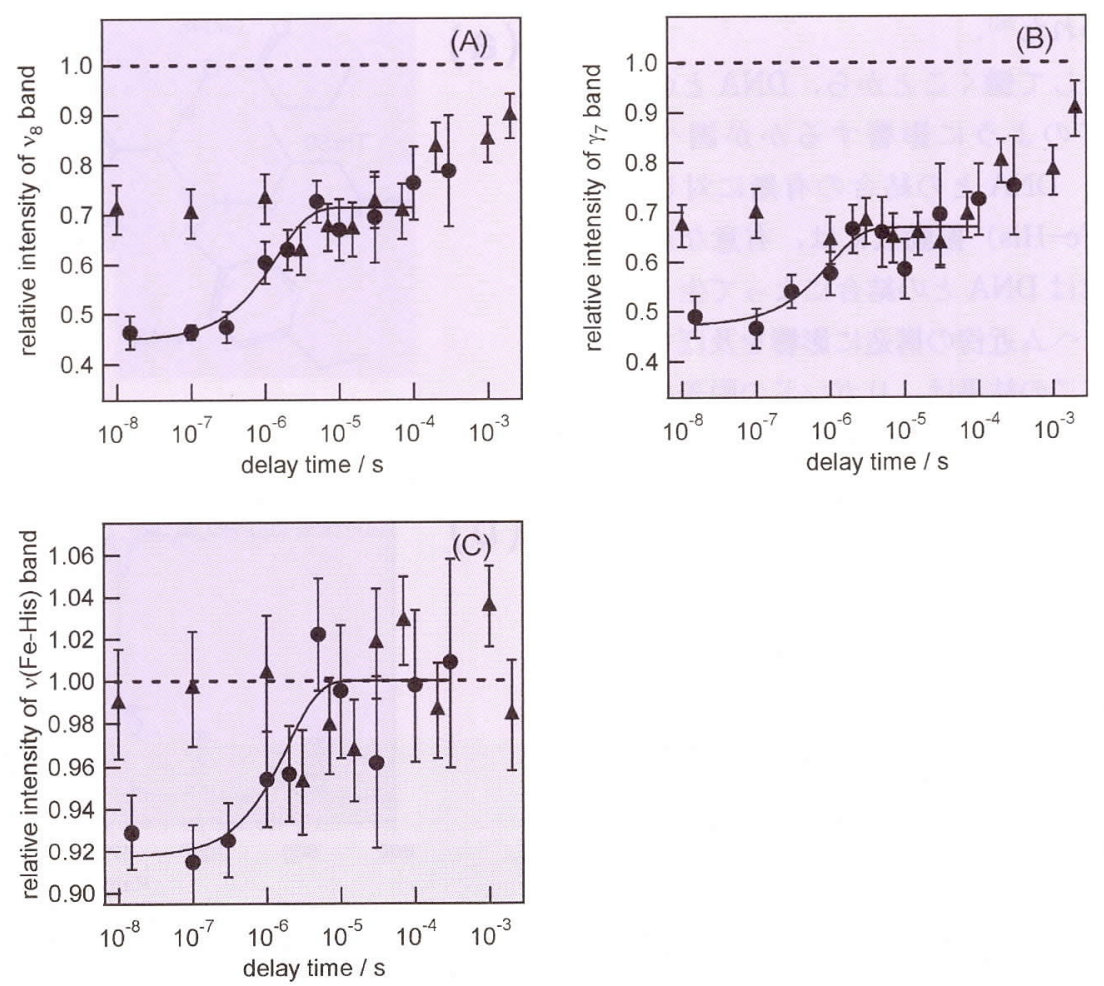

図 7 FixLのリガンド解離に伴う $\gamma_{7}, v_{8}, v$ ( Fe-His) ラマンバンド強度変化. 横軸は対数スケールで示してある. 三角と 丸は，それぞれ $\mathrm{CO}$ 解離抢よび $\mathrm{O}_{2}$ 解離に伴うラマンバンド強度を表す．実線は，1 つあるいは 2 つの指数関数の 和によって実測值をフィットしたものである.

に示す， $\mathrm{O}_{2}$ 解離の場合，v(Fe-His）バンド扔よびいくつ かのへム低波数バンド $\left(\gamma_{7}, v_{8}\right.$ バンド $)$ にいて，サブマ イクロ秒からマイクロ秒にかけてバンド強度の变化が観測 された。一方, $\mathrm{CO}$ 解離では，このような強度変化は観測 されなかった。したがって，これらのバンド強度の变化は， FixLのリガンド識別および $\mathrm{O}_{2}$ 検知に関与する構造変化 に由来すると考えられる。 また, $\mathrm{CO}$ 解離, $\mathrm{O}_{2}$ 解離とも に, 全長タンパク質ではセンサードメインのみのものに比 べて構造変化の速度が遅くなった．これは, 構造変化がキ ナーゼドメインと連動していることを強く示唆する、筆者 らは, 得られたデータを基にして, リガンド解離に伴う構 造変化のモデルを提案した。

b) HemAT

HemAT は，枯草菌 Bacillus subtilis に含まれるタンパ ク質で, 菌の $\mathrm{O}_{2}$ に対する走化性に関わる $\mathrm{O}_{2}$ センサーで ある. $\mathrm{N}$ 末端側のセンサードメインと $\mathrm{C}$ 末端側のシグナ リングドメインからなる72)。センサードメインはへムを 含み, $\mathrm{Mb}$ とアミノ酸配列の相同性をもっている。 セン サードメインについては結晶構造が明らかになっており， 近位 His とその近傍の Tyr133との間の距離変化から，リ ガンド結合に伴い，両者の間に水素結合が形成されること が示唆されている73).

筆者らは, ピコ秒時間分解可視共鳴ラマン分光法を用い て, リガンド解離に伴うへム周辺の構造变化を調べ
た ${ }^{74)}$ 。ここでは測定上の理由から，リガンドとして $\mathrm{O}_{2}$ で はなく, CO を用いている。野生型では, CO 解離後 $10 \mathrm{ps}$ から $1 \mathrm{~ns}$ にかて，2 $\mathrm{cm}^{-1}$ の低波数シフトが観測され た。これに対し，Tyr133をPheに置換した変異体では， このようなシフトは観測されなかった。 この結果は, リガ ソドの解離後, 近位 His 周辺に構造変化が起き, それは His の水素結合変化を伴うものであることを示唆している.

c) $\mathrm{CooA}$

CooA は，紅色非硫黄光合成細菌 Rhodosprillum rubrum に含まれる転写調節因子である。COセンサーとして働 き,この菌の CO 代謝に関わるタンパク質の発現を制御し ている. FixL, HemATの研究から, ガスセンサータン パク質においても $v(\mathrm{Fe}-\mathrm{His})$ バンドが，リガンド解離後 のへム周辺構造变化の分光学的プローブとして有効である ことがわかる. CooA の研究では, リガンド結合状態にお けるトランス軸配位子はHis と予想されていたが，当初 その実験的証拠はなかった。この軸配位子の同定には，ピ コ秒時間分解共鳴ラマン分光法は決定的な役割を果たし た。すなわち, リガンド光解離後, 過渡的に生じる 5 配 位状態のスペクトルに抏いて, $v(\mathrm{Fe}-\mathrm{His})$ バンドが見出 され，軸配位子がHisであることが同定されたのであ る75).リガンド結合状態で, トランス軸配位子が His で あることは, その後 X 線結晶構造解析によって確認され た。同様の方法で, $\mathrm{O}_{2}$ センサータンパク質である DOSの 
軸配位子の同定も行われた ${ }^{76)}$.

CooA は転写因子として働くことから，DNA との結合 がへム周辺構造にどのように影響するかが調べられ た ${ }^{77)}$. 意外なことに, DNA との結合の有無に対して, $\mathrm{CO}$ 解離後 $5 \mathrm{ps} の v(\mathrm{Fe}-\mathrm{His})$ 振動数には，有意な差は認 められなかった。これはDNA との結合によって生じた結 合部位の構造恋化は，へム近傍の構造に影響を及ぼさない ことを示唆している。この結果は,リガンドの脱着によっ てへム $\rightarrow$ DNA 結合部位の構造変化の伝搬が起きることを 考えると意外であった。へムと機能部位の連動性は方向性 をもっているのかもしれない。

ここで紹介した以外にも，へム含有センサータンパク質 について，共鳴ラマン分光法による研究が行われている が，ここでは紙面の関係で割愛した、へム含有センサーへ ムタンパク質の最近の進展については, Vosによる総説 ${ }^{78)}$ がある、興味のある方は参照されたい、

\subsection{2 イエロープロテイン}

PYP は, 紅色光合成細菌中に含まれ，この細菌が示す 負の走行性の光センサーであると考えられている.PYP 分子の構造は, PAS モチーフとよばれる構造からなる。 PAS モチーフは，FixLなど多くのセンサータンパク質に 含まれる共通の立体構造である。これらの共通立体構造 は, センサータンパク質のシグナル伝達に重要な役割を果 たしていることが予想される，このため，タンパク質の情 報伝達モデルとして，発色団とタンパク質部分がどのよう に連動しているかを調べることは，機構解明に不可欠であ る.

PYP の発色団周辺の構造を図 8 (a) に示す。発色団は $p-$ クマル酸であり, Cys69とのチオエステル結合によりタン パク質部分と結合している，暗状態の発色団は， $\mathrm{C}=\mathrm{C}$ 結 合がトランス構造をしており，フェノール環のヒドロキシ ル基は脱プロトン化している。また，カルボニル基は Cys69の主鎖と水素結合している.この局所構造は，光サ イクル中間体における発色団の可視共鳴ラマンスペクトル に現れるマーカーバンドにより決定することができる.

Unno らは, PYPの発色団の可視共鳴ラマンバンドに対 して，同位体置換体測定や密度汎関数法による計算を行 い，構造マーカーのバンドを帰属することで，光サイクル における構造変化を議論した ${ }^{79,80)}$. 発色団の光励起後, $\mathrm{pR}\left(\mathrm{PYP}_{\mathrm{L}}\right)$ 中間体に拈いてトランス $\rightarrow$ ス異性化抢よび カルボニル基のフリッピングが起こり，その後, $\mathrm{pB}$ $\left(\mathrm{PYP}_{\mathrm{M}}\right)$ 中間体で発色団のプロトン化抢よび逆異性化が 起こることを見出した。 また, Pan らは, 時間分解ラマン 測定の結果から，C $=\mathrm{C}$ 結合に抢ける水素原子の面外变角 振動バンドに注目し, $\mathrm{pB}^{\prime}$ 状態と呼ばれる中間体では $\mathrm{C}=$ C 結合周りで大きくねじれた構造をしていることを示し た 81 .

タンパク質部分の構造ダイナミクスについては, 紫外共 (a)

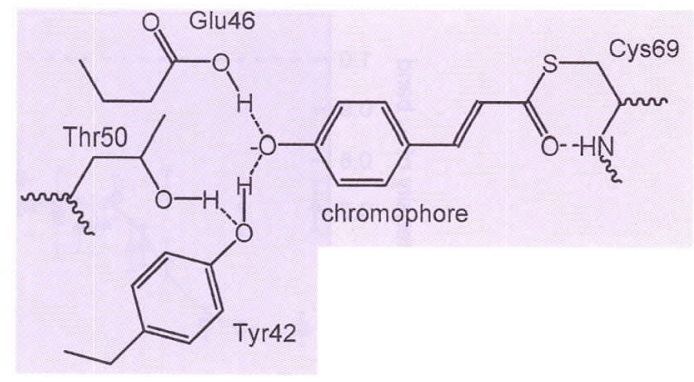

(b)
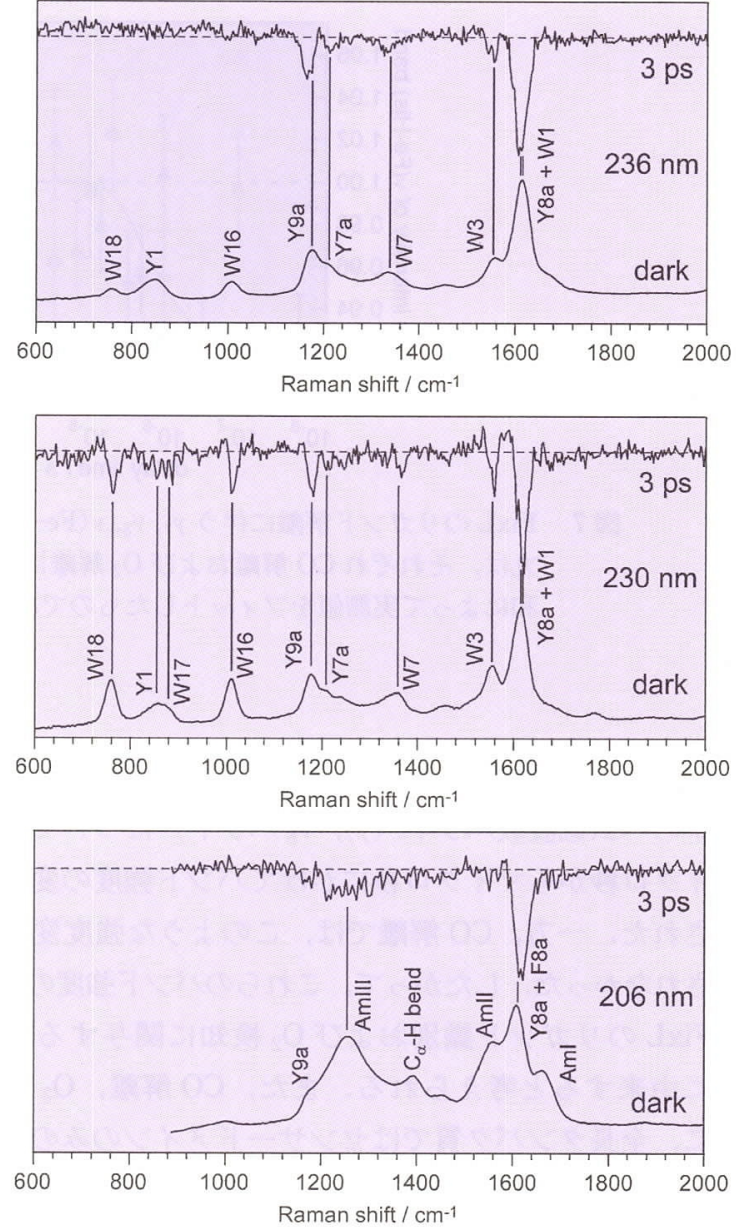

図 8 (a) PYP の発色団周辺のアミノ酸残基の構造. (b) PYPの紫外共鳴ラマンスペクトル．上段： 3 ps に掠 ける時間分解差スペクトル.下段 : 暗状態のスペクト ル(ただし，強度は30で割ってある)。プローブ波長 は各スペクトルに記載している。各振動モードの帰属 は Harada と Takeuchi ${ }^{21}$ による帰属に従う。

鳴ラマン分光法により新しい情報が, 最近相次いで報告さ れた。筆者らは, 時間分解紫外共鳴ラマン分光法を用いて, Tyr P Trp 残基，およびペプチド結合に由来する振動バ ンドのスペクトル変化から, PYPのピコ秒時間領域に抢 けるタンパク質部分の構造ダイナミクスを観測した ${ }^{82)}$. 図 8(b)に, PYP の光励起後 3 ps における暗状態上の時間 分解紫外共鳴ラマン差スペクトル (上段), および暗状態 の紫外共鳴ラマンスペクトル（下段）を示す。差スペクト 
ルに見られる負のバンドは, 暗状態のスペクトルと比較し て初期中間体のバンド強度が減少していることを表してい る.観測に用いたプローブ波長（236，230，および206 $\mathrm{nm}$ ）では，それぶれ，Tyr残基，Trp残基，およびペプ チド結合に由来するバンドが主に観測された，Tyr残基に ついては Y8a, Y7a，および $\mathrm{Y} 9 \mathrm{a}$ バンドに，Trp残基に ついてはW3, W7, W16, およびW18バンドに明らかな 強度減少が観測された。また，ペプチド結合については， アミドIII゙ンドに強度減少が観測された。

PYP 中に, Tyr 残基が 5 個, Trp 残基が 1 個存在する. Tyr 残基のスペクトル変化は, 発色団と直接水素結合して いるTyr 残基であるTyr42の寄与の可能性が最も高く, 観測されたスペクトル変化は, 発色団周辺の水素結合強度 の变化に由来すると考えられる，すなわち，スペクトル変

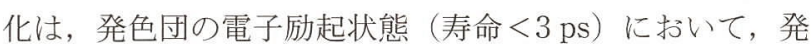
色団々Tyr42の間の水素結合強度は強化されていること を示している。ささら，ピコ秒領域におけるバンド強度に は，発色団とTyr42の間の水素結合強度が発色団のトラ ンス $\rightarrow$ ス異性化に応答して弱くなることを示寸変化が観 測された。一方, $\operatorname{Trp}$ 残基のスペクトル変化は, 唯一の Trp 残基でめる Trp1190構造変化に帰属される. Trp119 は発色団から $12 \AA$ 離れた位置にあることを考えると，こ のスペクトル変化は, 発色団から比較的遠くに離れた位置 においても構造変化が速く伝わっていることを示してい る. また, アミド振動バンドのスペクトル変化にも, 発色 団の光励起に応答したタンパク骨格構造の非常に速い変化 が観測された．これらの結果は，PYPの光応答によるタ ンパク質構造変化が, 数ピコ秒のうちに広範囲に及んでい ることを示唆している.

El-Mashtolyらは，PYPのシグナル状態と考えられて いる長寿命（数百ミリ秒）の $\mathrm{pB}$ 中間体を, 連続光照射下 で定常的に蓄積し, 紫外共鳴ラマンスペクトルを測定し た ${ }^{83)}$. $\mathrm{pB}$ 中間体と暗状態の紫外共鳴ラマン差スペクトル

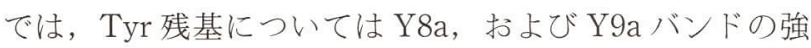
度変化と高波数シフトが観測された．差スペクトル中のバ ンド形のプローブ波長依存性や解析により, Tyr 残基の大 ペクトル変化が Tyr42 と Tyr118の構造変化に由来するこ とが示さ机た．また，変異体（Thr50 $\rightarrow$ Val）の測定によ り, 彼らは, pB 中間体では, 発色団とTyr42との間の水 素結合が弱まるか，もしくは切断されると推定した．Trp 残基のスペクトル変化については，W3，W16，および W18バンドの強度減少が観測された。このスペクトル変 化は， $\mathrm{N}$ 末端側（活性部位と考えられている）のシグナ ル状態における部分的なアンフォールディングによって, Trp119残基が溶媒へ露出したことに由来すると帰属され た.

\section{3 連動性によるエネルギー変換}

生物は外部からエネルギーを取り入れ，それをもとに
ATP を合成している.このエネルギ一変換の過程には, プロトンポンプとよばれる膜タンパク質が関与している. これは, タンパク質に起きる化学反応と共役して, プロト ンを, 膜で隔てられた一方の空間からもう一方の空間へ輸 送する働きをもつ，このとき生じる，膜を隔てたプロトン 濃度差による化学ポテンシャルが, ATP 合成に利用され る (化学浸透圧説). プロトンポンプは, 化学反応で発生 するエネルギーによって構造変化を誘起し, プロトンを一 万向に輸送する, つまり, プロトンポンプは, タンパク質 構造変化とタンパク質内水素結合ネットワークが連動する ことにより達成されているのである.ここでは $2 つ の$ 代 表的なプロトンポンプについて研究例を紹介する.

\subsection{1 チトクロム酸化酵素}

チトクロム酸化酵素は, ミトコンドリアの内膜にあって, $\mathrm{O}_{2}$ 分子の水への還元反応を触媒するとともに, その反応 で発生したエネルギーを利用し，水素イオンをマトリック スから膜間腔へ汲久出すプロトンポンプである。したがっ て, 酸化還元反応とプロトン輸送との連動性を明らかにす ることが，この酵素の機能発現機構を理解する鍵となる。

還元反応は，高酸化状態のへムを中間体として経由して 起きる. $\mathrm{O}_{2}$ 分子の水への還元反応機構を明らかにするに は，その反応中間体の構造を調べることが重要である。 Ogura らは, 反応中間体のへム構造を, 時間分解共鳴 マン分光法を用いて調べた43)。その結果を図 9 に示す。

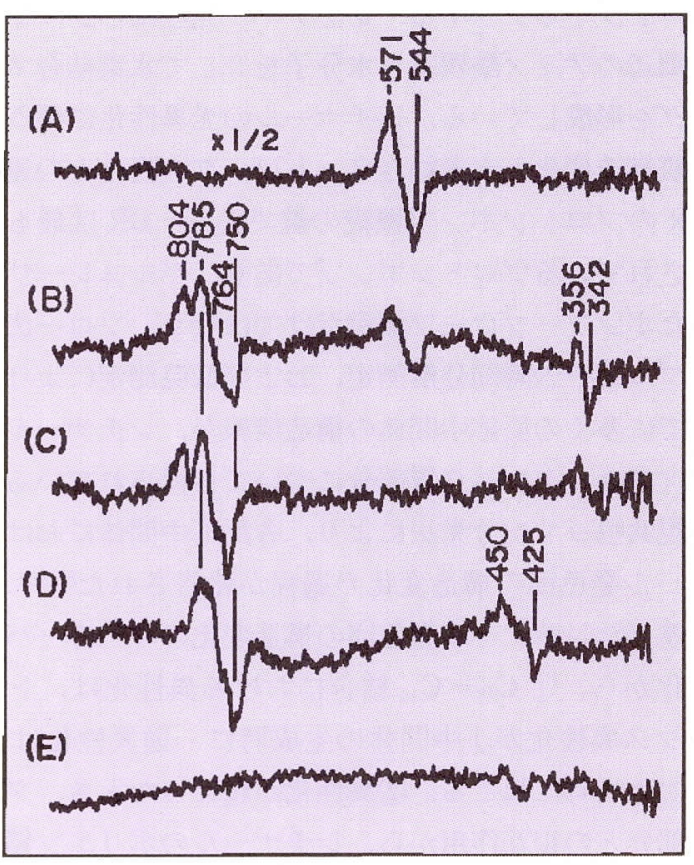

RAMAN SHIFT/ $\mathrm{cm}^{-1}$

図 9 チトクロム酸化酵素の時間分解共鳴ラマンスペクト ル、スペクトルは, 基質である酸素として ${ }^{16} \mathrm{O}_{2}$ を加 えた場合と ${ }^{18} \mathrm{O}_{2}$ を加えた場合の差スペクトルで示し てある、酸素分子との反応開始後の時間はそれぞれ， 0.1 (A), 0.27 (B), 0.54 (C), 2.7 (D), 5.4 (E) ms であ る. (文献 ${ }^{43)}$ より許可老得て転載) 
これは時刻ゼロで $\mathrm{O}_{2}$ 分子との反応をスタートさせ，その 後の時間分解スペクトルを示していて, 基質である $\mathrm{O}_{2}$ と して ${ }^{16} \mathrm{O}_{2}$ を加えた場合と ${ }^{18} \mathrm{O}_{2}$ を加えた場合の差スペクト ルが示してめる．生スペクトルにはへムの骨格振動モード による多くのバンドが強く観測されるが， ${ }^{16} \mathrm{O}_{2} /{ }^{18} \mathrm{O}_{2}$ 差ス ペクトルではこれらは相殺され，へム鉄と $\mathrm{O}_{2}$ との振動の みが現れる．このようにしていくつかの酵素反応中間体の $\mathrm{Fe}-\mathrm{O}$ 伸縮振動が検出された。この結果から中間体のへム 構造が決定され，どのような反応中間体を経由して $\mathrm{O}_{2}$ が $\mathrm{H}_{2} \mathrm{O}$ へ還元されるかが明らかにされた。 また，緩衝液の 重水置換によって速度が著しく低下するステップが観測さ れ，酸化還元反応のステップとプロトン輸送との連動が議 論された。

この測定は，共鳴効果と同位体シフトを利用することに よって，巨大分子の中の 1 本の化学結合を，振動スペク トルで検出しているものであることに注目されたい，化学 結合を観る振動分光法の特徵を活かした反応解析の好例と いえる. Ogura らは測定装置に改良を加え, 最近, ミト コンドリアのままで同様の実験を行った ${ }^{84)}$. 可溶化した 試料と同様の中間体が観測されたが，その寿命は大きく異 なっていた。これはミトコンドリア内膜での環境が反応速 度に影響を与えていることを示している。

\subsection{2 バクテリオロドプシン}

BR は，高度好塩菌の紫膜中に含まれる膜タンパク質 で，光エネルギーを利用して細胞の内側から外側へ能動的 にプロトンをポンプする、レチナール発色団のシッフ塩基 は，周辺のアミノ酸残基と水分子を介して水素結合ネット ワークを形成している．レチナールの光異性化に伴うタン パク質構造変化と水素結合ネットワークの変化との連動性 が BRのプロトンポンプ機構の鍵である. BR は最もよく 研究されているプロトンポンプであり，パルスレーザーを 用いたポンプープローブ測定だけではなく，フロー法によ るダブルビーム時間分解測定，および低温測定により，こ れまでに多くの反応中間体の構造情報が，レチナール発色 団だけでなくタンパク質部分についても得られている.

可視共鳴ラマン分光法により，各反応中間体におけるレ チナール発色団の構造变化の過程が報告された ${ }^{85,86)} .2 .2$ 節で述べたレチナール発色団の構造変化のマーカーバンド の変化から, (1) $\mathrm{C}_{13}=\mathrm{C}_{14}$ 結合に抢ける異性化は, トラン ス $\rightarrow$ ス異性化が $\mathrm{J}$ 中間体の生成時に，逆異性化は $\mathrm{O}$ 中 間体の生成時に起こる，(2)異性化が起こったとき，タンパ ク質部分との相互作用から，レチナールのポリエン鎖が大 きくねじれる（J林び $\mathrm{O}$ 中間体），(3)プロトンポンプに 重要なシッフ塩基の脱プロトン化は $\mathrm{M}$ 中間体の生成に伴 い起こる，ことが見出された。また，20-100 psの間で は，低温測定では観測されない，異性化によりタンパク構 造のコンフォメーションが変化した KL 中間体が存在する ことが示された ${ }^{85)}$.このようなレチナール発色団の構造
変化が，周辺のタンパク質構造や水素結合ネットワークの 構造ダイナミクスと連動していると考えられる.

一方, タンパク質部分の構造変化については, 紫外共鳴 ラマンスペクトルに基づいて議論がなされている. Hashimoto らは，フロー法による時間分解ラマン測定を 行い，レチナール発色団を挟むように取り团むFへリッ クス上の Trp182 と $\operatorname{Trp} 189$ 残基の $\mathrm{L} ， \mathrm{M}$ ，抢よび $\mathrm{N}$ 中間 体におけるスペクトルを測定し，光サイクル後半に現れる 反応中間体のタンパク構造ダイナミクスを議論した ${ }^{87)}$. $\mathrm{M}_{1} \rightarrow \mathrm{M}_{2}$ 中間体の過程では, Trp182の水素結合が強化さ れ，かつTrp189の疎水性相互作用が大きくなることに対 応する変化が観測された。このことから，Fヘリックスが この過程で傾くことが明らかになった. $\mathrm{M}_{2} \rightarrow \mathrm{N}$ 中間体の 過程では, Trp1820蹯水性相互作用が残基周辺への水分 子の侵入により劇的に減少し，Trp189の構造が初期状態 へと戻ることが示唆された。 また，初期過程に現れる中間 体については, Kaminaka らが10 nsにおける KL中間体 についての紫外共鳴ラマンスペクトルを報告してい る ${ }^{88)}$ 。このスペクトルでは, 透過率の高い前置分光器を 用いた迷光除去を行った結果，それ以前に報告されたスぺ クトル ${ }^{89)}$ に比べ大幅に質が改善されている．筆者らは，

最近，BRについてピコ秒時間分解紫外共鳴ラマン測定を 行い, $\operatorname{Trp}$ 残基残基周辺のタンパク質構造には, $30 \mathrm{ps}$ の 時定数を示すダイナミクスが存在することを見出し た ${ }^{90)}$. プロトンポンプでは，カルボン酸を側鎖にもつア ミノ酸残基が重要な役割を果たし，それらは赤外吸収スペ クトルで感度よく観測される. 紫外共鳴ラマン分光法と赤 外分光法とを相補的に用いることによって，機構の理解が より進むと期待される。

\section{5. まとめ}

本稿では，「連動性が生み出すタンパク質機能の分子科 学」という視点から, 時間分解共鳴ラマン分光法を用いた タンパク質ダイナミクス研究を, 筆者らの研究を中心に述 ベた.

研究していて感じることは，「タンパク質分子は実にう まくできている」ということである. タンパク質では, 複 数の相互作用がうまくバランスし, 複数のプロセスの連動 性を生み出している. 連動性によって巧久に働く分子機械 であるタンパク質は，われわれの知的好奇心を引き付ける 美しさをもつ.

タンパク質を研究し，それを基に生命現象を理解しよう という流れがあり，それは分子生物学，生物物理学という 学術領域として発展してきた. 一方, タンパク質という高 い連動性をもつ分子を研究することは，分子一般について の理解を深める. そのような研究の発展のためには, 分光 法を単なる分析手段として用いるだけではなく, 分光学が もつ可能性を新しく開拓する必要がある．分光学を基盤々 
して，この「タンパク質の分子科学」とよぶべき分野の発 展に少しでも貢献していきたいと考えている.

\section{謝辞}

本稿で紹介した筆者らの研究成果は, 参考文献に打名前 を挙げさせていただいた多くの共同研究者との協力のもと に得られたものである.これらの方々に深く感謝する。

\section{参考文献}

1) R. E. Dickerson and I. Geiss: Hemoglobin: Structure, Function, Evolution, and Pathology. (Benjamin Cummings, Menlo Park, 1983).

2) D. A. Case and M. Karplus: J. Mol. Biol. 132, 343 (1979).

3) S. K. Lüdemann, V. Lounnas, and R. C. Wade: J. Mol. Biol. 303, 797 (2000).

4) S. K. Lüdemann, V. Lounnas, and R. C. Wade: J. Mol. Biol. 303, 813 (2000).

5) T. G. Spiro and T. C. Strekas: Proc. Natl. Acad. Sci. USA 69, 2622 (1972).

6) M. Abe, T. Kitagawa, and Y. Kyogoku: J. Chem. Phys. 69, 4526 (1978)

7) T. Kitagawa, M. Abe, and H. Ogoshi: J. Chem. Phys. 69, 4516 (1978).

8) X. Y. Li, R. S. Czernuszewicz, J. R. Kincaid, P. Stein, and T. G. Spiro: J. Phys. Chem. 94, 47 (1990).

9) M. L. Mitchell, X. Y. Li, J. R. Kincaid, and T. G. Spiro: J. Phys. Chem. 91, 4690 (1987).

10) S. Hu, K. M. Smith, and T. G. Spiro: J. Am. Chem. Soc. 118, 12638 (1996).

11) T. G. Spiro and X.-Y. Li: in Biological Applications of Raman Spectroscopy, edited by T. G. Spiro (John Wiley \& Sons, New York, 1987), Vol. III, pp. 1.

12) T. Kitagawa, T. Iizuka, M. Saito, and Y. Kyogoku: Chem. Lett. 4, 849 (1975).

13) T. G. Spiro and J. M. Burke: J. Am. Chem. Soc. 98,5482 (1976).

14) S. Choi, T. G. Spiro, K. C. Langry, K. M. Smith, D. L. Budd, and G. N. La Mar: J. Am. Chem. Soc. 104, 4345 (1982).

15) L. D. Spaulding, C. C. Chang, N.-T. Yu, and R. H. Felton: J. Am. Chem. Soc. 97, 2517 (1975).

16) T. Kitagawa: in Biological Applications of Raman Spectroscopy, edited by T. G. Spiro (John Wiley \& Sons, New York, 1987), Vol. III, pp. 97.

17) S. O. Smith, A. B. Myers, R. A. Mathies, J. A. Pardoen, C. Winkel, E. M. v. d. Berg, and J. Lugtenburg: Biophys. J. 47, 653 (1985).

18) S. O. Smith, M. S. Braiman, A. B. Myers, J. A. Pardoen, J. M. L. Courtin, C. Winkel, J. Lugtenburg, and R. A. Mathies: J. Am. Chem. Soc. 109, 3108 (1987).

19) S. O. Smith, J. A. Pardoen, J. Lugtenburg, and R. A. Mathies: J. Phys. Chem. 91, 804 (1987).

20) R. A. Mathies, S. O. Smith, and I. Palings: in Biological Applications of Raman Spectroscopy, edited by T. G. Spiro (John Wiley \& Sons, New York, 1987), Vol. II, pp. 59.

21) I. Harada and H. Takeuchi: in Advances in Spectroscopy, edited by R. J. H. Clark and R. E. Hester (John Wiley \& Sons Chichester, 1986), pp. 113.
22) T. Kitagawa: Prog. Biophys. Mol. Biol. 58, 1 (1992).

23) T. Kitagawa and S. Hirota: in Handbook of Vibrational Spectroscopy, edited by J. M. Chalmers and P. R. Griffiths (John Wiley \& Sons, Chichester, 2002), pp. 3426.

24) R. P. Rava and T. G. Spiro: J. Phys. Chem. 89, 1856 (1985).

25) C. R. Johnson, M. Ludwig, and S. A. Asher: J. Am. Chem. Soc. 108, 905 (1986).

26) M. Ludwig and S. A. Asher: J. Am. Chem. Soc. 110, 1005 (1988).

27) S. A. Asher, M. Ludwig, and C. R. Johnson: J. Am. Chem. Soc. 108, 3186 (1986).

28) J. A. Sweeney and S. A. Asher: J. Phys. Chem. 94, 4784 (1990).

29) M. Matsuno and H. Takeuchi: Bull. Chem. Soc. Jpn. 71, 851 (1998).

30) H. Takeuchi, N. Watanabe, Y. Sato, and I. Harada: J. Raman Spectrosc. 20, 233 (1989).

31) Z. Chi and S. A. Asher: J. Phys. Chem. B 102, 9595 (1998).

32) T. Miyazawa, T. Shimanouchi, and S. Mizushima: J. Chem. Phys. 29, 611 (1958).

33) S. Krimm and J. Bandekar: Adv. Protein Chem. 38, 181 (1986)

34) R. A. Copeland and T. G. Spiro: Biochemistry 26, 2134 (1987).

35) X. G. Chen, S. A. Asher, R. Schweitzer-Stenner, N. G. Mirkin, and S. Krimm: J. Am. Chem. Soc. 117, 2884 (1995).

36) Z. Chi, X. G. Chen, S. W. Holtz, and S. A. Asher: Biochemistry 37, 2854 (1998).

37) S. A. Asher, A. Ianoul, G. Mix, M. N. Boyden, A. Karnoup, M. Diem, and R. Schweitzer-Stenner: J. Am. Chem. Soc. 123, 11775 (2001).

38) C.-Y. Huang, G. Balakrishnan, and T. G. Spiro: Biochemistry 44,15734 (2005).

39) I. K. Ledonev, A. S. Karnoup, M. C. Sparrow, and S. A. Asher: J. Am. Chem. Soc. 121, 8074 (1999).

40) I. K. Ledonev, A. S. Karnoup, M. C. Sparrow, and S. A. Asher: J. Am. Chem. Soc. 121, 4076 (1999).

41) S. Matsumoto, A. Yane, S. Nakashima, M. Hashida, M. Fujita, Y. Goto, and S. Takahashi: J. Am. Chem. Soc. 129, 3840 (2007).

42) D. Pan and R. A. Mathies: Biochemistry 40, 7929 (2001).

43) T. Ogura, S. Hirota, D. A. Proshlyakov, K. Shinzawa-Itoh, S. Yoshikawa, and T. Kitagawa: J. Am. Chem. Soc. 118, 5443 (1996).

44) J. B. Ames, S. P. A. Fodor, R. Gebhard, J. Raap, E. M. M. Van den Berg, J. Lugtenburg, and R. A. Mathies: Biochemistry 28, 3681 (1989)

45) S. P. A. Fodor, J. B. Ames, R. Gebhard, E. M. M. Van den Berg, W. Stoeckenius, J. Lugtenburg, and R. A. Mathies: Biochemistry 27, 7097 (1988).

46) S. P. A. Fodor, W. T. Pollard, R. Gebhard, E. M. M. V. D. Berg, J. Lugtenburg, and R. A. Mathies: Proc. Natl. Acad. Sci. USA 85, 2156 (1988).

47) S. O. Smith, J. A. Pardoen, P. P. J. Mulder, B. Curry, J. Lugtenburg, and R. Mathies: Biochemistry 22, 6141 (1983).

48）水谷泰久：生物物理 47, 288 (2007).

49) Y. Uesugi, Y. Mizutani, S. G. Kruglik, A. G. Shvedko, V. A. Orlovich, and T. Kitagawa: J. Raman Spectrosc. 31, 339 (2000). 
50) M. J. Tauber, R. A. Mathies, X. Chen, and S. E. Bradforth: Rev. Sci. Instrum. 74, 4958 (2003).

51) S. Kaminaka and R. A. Mathies: Appl. Spectrosc. 52, 469 (1998).

52 ) http://www.roper.co.jp/industrial_science_image/tech_ note/tech_notes.shtml

53) J. S. Olson and G. N. Phillips: J. Biol. Chem. 271, 17593 (1996).

54) G. S. Kachalova, A. N. Popov, and H. D. Bartunik: Science 284, 473 (1999).

55) S. Franzen, B. Bohn, C. Poyart, and J. L. Martin: Biochemistry 34, 1224 (1995).

56) Y. Mizutani and T. Kitagawa: Science 443 (1997).

57) Y. Mizutani and T. Kitagawa: J. Phys. Chem. B 105, 10992 (2001).

58) S. Matsukawa, K. Mawatari, Y. Yoneyama, and T. Kitagawa: J. Am. Chem. Soc. 107, 1108 (1985).

59) E. W. Findsen, J. M. Friedman, M. R. Ondrias, and S. R. Simon: Science 229, 661 (1985).

60) E. W. Findsen, T. W. Scott, M. R. Chance, J. M. Friedman, and M. R. Ondrias: J. Am. Chem. Soc. 107, 3355 (1985).

61) T. W. Scott and J. M. Friedman: J. Am. Chem. Soc. 106, 5677 (1984).

62) G. Fermi and M. F. Perutz: Haemoglobin and Myoglobin, Atlas of Molecular Structures in Biology, Vol. 2. (Oxford University Press, New York, 1981).

63) S. Kaminaka and T. Kitagawa: J. Am. Chem. Soc. 114, 3256 (1992).

64) K. R. Rodgers, C. Su, S. Subramaniam, and T. G. Spiro: J. Am. Chem. Soc. 114, 3697 (1992).

65) G. Balakrishnan, M. A. Case, A. Pevsner, X. Zhao, C. Tengroth, G. L. McLendon, and T. G. Spiro: J. Mol. Biol. 340, $843(2004)$.

66) J. E. Kim, D. Pan, and R. A. Mathies: Biochemistry 42, 5169 (2003).

67) A. Sato, Y. Gao, T. Kitagawa, and Y. Mizutani: Proc. Nat1. Acad. Sci. USA 104, 9627 (2007).

68) A. Sato and Y. Mizutani: Biochemistry 44, 14709 (2005).

69) E. Culotta and J. D. E. Koshland: Science 258, 1862 (1992).

70) R. V. Swanson, L. A. Alex, and M. I. Simon: Trends Biochem. Sci. 19, 485 (1994).

71) Y. Hiruma, A. Kikuchi, A. Tanaka, Y. Shiro, and Y. Mizutani: Biochemistry 46, 6086 (2007).

72) S. Hou, R. W. Larsen, D. Boudko, C. W. Riley, E. Karatan, M. Zimmer, G. W. Ordal, and M. Alam: Nat. Aust. 403, 540 (2000).

73) W. Zhang and G. N. Phillips: Jr., Structure 11, 1097 (2003).

74) H. Yoshimura, S. Yoshioka, Y. Mizutani, and S. Aono: Biochem. Biophys. Res. Commun. 357, 1053 (2007).

75) T. Uchida, H. Ishikawa, K. Ishimori, I. Morishima, H. Nakajima, S. Aono, Y. Mizutani, and T. Kitagawa: Biochemistry 39, 12747 (2000).
76) A. Sato, Y. Sasakura, S. Sugiyama, I. Sagami, T. Shimizu, Y. Mizutani, and T. Kitagawa: J. Biol. Chem. 277, 32650 (2002).

77) M. Kubo, S. Inagaki, S. Yoshioka, T. Uchida, Y. Mizutani, S. Aono, and T. Kitagawa: J. Biol. Chem. 281, 11271 (2006).

78) M. H. Vos: Biochim. Biophys. Acta 1777, 15 (2008).

79) M. Unno, M. Kumauchi, J. Sasaki, F. Tokunaga, and S. Yamauchi: Biochemistry 41, 5668 (2002).

80) M. Unno, M. Kumauchi, J. Sasaki, F. Tokunaga, and S. Yamauchi: J. Phys. Chem. B 107, 2837 (2003).

81) D. Pan, A. Philip, W. D. Hoff, and R. A. Mathies: Biophys. J. 86, 2374 (2004).

82) M. Mizuno, N. Hamada, F. Tokunaga, and Y. Mizutani: J. Phys. Chem. B 111, 6293 (2007).

83) S. F. El-Mashtoly, S. Yamauchi, M. Kumauchi, N. Hamada, F. Tokunaga, and M. Unno: J. Phys. Chem. B 109, 23666 (2005).

84) T. Takahashi, S. Kuroiwa, T. Ogura, and S. Yoshikawa: J. Am. Chem. Soc. 127, 9970 (2005).

85) S. J. Doig, P. J. Reid, and R. A. Mathies: J. Phys. Chem. 95, $6372(1991)$

86) S. O. Smith, J. Lugtenburg, and R. A. Mathies: J. Membr. Biol. 85, 95 (1985).

87) S. Hashimoto, M. Sasaki, H. Takeuchi, R. Needleman, and J. K. Lanyi: Biochemistry 41, 6495 (2002).

88) S. Kaminaka and R. A. Mathies: Laser Chem. 19, 165 (1999).

89) J. B. Ames, M. Ros, J. Raap, J. Lugtenburg, and R. A. Mathies: Biochemistry 31, 5328 (1992).

90) 水野 操, 柴田幹夫, 神取秀樹, 水谷泰久: 第35回生体分 子科学討論会要旨集 (2008), 講演番号 30 .

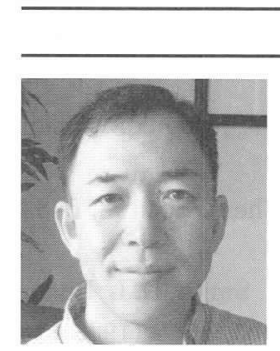

\section{PROFILE}

水谷泰久 大阪大学大学院理学研究科 教授 博 士 (理学)

〔略歴〕1987年京都大学工学部工業化学科卒業, 1989年京都大学大学院工学研究科分子工学専攻 修士課程修了, 1992年総合研究大学院大学数物 科学研究科博士課程修了. その後, 日本学術振興 会特別研究員, 岡崎国立共同研究機構分子科学研 究所助手, 神戸大学分子フォトサイエンス研究セ ンター助教授を経て, 2006年 4 月より現職. [専門]生物物理化学

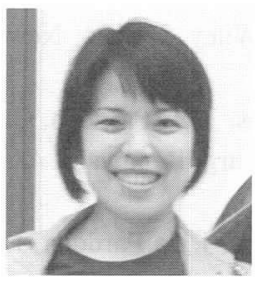

水野 操 大阪大学大学院理学研究科 助教 博 土 (理学)

[略歴] 1996年早稲田大学理工学部化学科卒業, 1999年早稲田大学大学院理工学研究科化学専攻 後期博士課程中退，岡崎国立共同研究機構分子科 学研究所技官, 独立行政法人理化学研究所協力研 究員, 日本学術振興会特別研究員 (PD) を経て, 2007 年 8 月より現職. [専門]分子分光学, タン 